\title{
Jafnréttisskorkort fyrir íslenskt atvinnulíf
}

\author{
Snjólfur Ólafsson, Lára Jóhannsdóttir, Sigríður Finnbogadóttir, Erla S. \\ Kristjánsdóttir, Póra H. Christiansen og Pórunn Sigurðardóttir ${ }^{1}$
}

\begin{abstract}
Ágrip
Í íslensku atvinnulífi er talsverður kynjahalli prátt fyrir aðgerðir sem ætlað er að draga úr honum. Hér hallar á konur. Pví er kallað eftir bættri stöðu, t.d. varðandi laun og kynjahlutfall í stjórnunarstöðum. Petta er flókið viðfangsefni en mikilvæg atriði hafa verið dregin fram í áhrifariti sem sýnir meginatriðin og hvernig pau tengjast innbyrðis. Meðal helstu atriða eru launamunur kynjanna, fjölskylduábyrgð, frami kvenna innan fyrirtækja og staðalmyndir kynjanna. Markmið rannsóknarinnar er að draga fram á skipulegan hátt safn mælikvarða, í formi jafnréttisskorkorts, til að meta stöðu kynjanna í íslensku atvinnulífi. Rannsóknarspurningarnar sem lagt var upp með voru: Hvaða safn mælikvarða, sett fram í jafnréttisskorkorti, gefur heildarmynd af stöðu kynjanna í íslensku atvinnulífi? og Hver er staða kynjanna í íslensku atvinnulífi samkvæmt jafnréttisskorkortinu? Niðurstöðurnar og meginframlag rannsóknarinnar er jafnréttisskorkortið sem og samantekt tölulegra gagna sem tengjast mælikvörðum í skorkortinu. Jafnréttisskorkortið getur gagnast í rannsóknum til að sýna stöðu kynjanna og hvernig hún próast. Pað hefur einnig hagnýtt gildi fyrir pá sem vinna að pví að jafna stöðu kynjanna í íslensku atvinnulífi, hoort heldur sem er stjórnvöld eða aðilar vinnumarkaðarins.
\end{abstract}

\begin{abstract}
Despite extensive efforts to reduce gender inequality, considerable gender bias can still be found in the Icelandic labor market. Women are at a disadvantage and as a result improvements are called for to e.g. close the wage gap and eliminate the gender bias in senior management. An influence map has revealed the key factors and relationships that contribute to this complex issue. The strongest contributors are the gender wage gap, family responsibility, women's professional advancement in organizations, and gender stereotypes. This study aims to systematically identify a collection of measurements to form a gender equality scorecard that can serve as a numerical indicator of the level of balance between women and men in the Icelandic labor market. The research questions are: Which measurements, collectively presented in a gender equality scorecard, effectively represent the level of balance between women and men in the Icelandic labor market? and What is the level of balance between women and men in the Icelandic labor market according to the gender equality scorecard? The resulting gender equality scorecard and collection of numerical measures pre-
\end{abstract}

1 Snjólfur Ólafsson er prófessor við Viðskiptafræðideild Háskóla Íslands. Netfang: snjolfur@hi.is. Lára Jóhannsdóttir er prófessor við Umhverfis- og auðlindafræði, Háskóli Íslands. Netfang: laraj@hi.is. Erla S. Kristjánsdóttir er dósent við Viðskiptafræðideild Háskóla Íslands. Netfang: esk@hi.is. Póra H. Christiansen er aðjúnkt við Viðskiptafræðideild Háskóla Íslands. Netfang: thc@hi.is. Sigríður Finnbogadóttir er sérfræðingur með MS í stjórnun og stefnumótun frá Háskóla Íslands. Netfang: sif2@hi.is. Pórunn Sigurðardóttir er hjúkrunarfræðingur með MS í viðskiptafræði frá Háskóla Íslands. Netfang: thorunnsig@yahoo.com.

This work is licensed under a Creative Commons Attribution 4.0 License.

DOI: https://doi.org/10.24122/tve.a.2020.17.1.4

(C) Tímarit um viðskipti og efnahagsmál

www.efnahagsmal.is 
sented are the main contribution of this study. The gender equality scorecard can be used in research of the gender balance and how it evolves. It can also have a practical application for anyone, working on eliminating the gender imbalance in the Icelandic labor market, be they the government or labour market participants.

JEL flokkun: M14, M51

Lykilorð: Staða kynjanna; skorkort; mælikvarðar; atvinnulíf; frami kvenna.

Keywords: Gender equality; scorecard; measurements; work; women's advancement.

\section{Gender Equality Scorecard for the Icelandic labor market}

\section{Inngangur}

Barátta fyrir jafnrétti kynjanna hefur staðið yfir lengi og gerir enn. Á Íslandi hefur mikið áunnist á pessu sviði eins og sést best í alpjóðlegum samanburði, en pó er langt í land að fullu jafnrétti sé náð. Pví má spyrja: Hver er staðan í raun? Hve mikið vantar upp á að fullu jafnrétti sé náð? Er hægt að mæla kynjajafnrétti? Hvaða tölur gefa góða mynd af kynjajafnrétti?

Pessi rannsókn takmarkast við jafnrétti kynjanna í atvinnulífinu og atriði sem talin eru að stuðli að pví. Hún einskorðast við jafnrétti kvenna og karla en ekki annarra hópa, t.d. innflytjenda eða fatlaðs fólks og með jafnrétti kynjanna er átt við jafna stöðu kvenna og karla frekar en lagalegt jafnrétti. Rannsóknin einskorðast við atvinnulífið pannig að ýmsar aðrar hliðar kynjajafnréttis, t.d. jafnrétti í ípróttum, listum og menntakerfinu, eru utan afmörkunar pessarar rannsóknar og greinar, nema að pví marki sem pær eru taldar hafa áhrif á jafnrétti í atvinnulífinu. Pá er heldur ekki verið að leggja mat á frammistöðu einstakra fyrirtækja á sviði kynjajafnréttis.

Af og til eru dregnar fram tölur sem segja til um stöðuna varðandi jafnrétti kynjanna í atvinnulífinu. Par má nefna tölur varðandi kynbundinn launamun og kynjaskipt atvinnulíf (Porgerður Einarsdóttir og Kristjana Stella Blöndal, 2004) eða hlutfall kvenna í framkvæmdastjórn (Ásta Dís Óladóttir, Gylfi Dalmann Aðalsteinsson og Póra H. Christiansen, 2019). Pessar rannsóknir veita mikilvægar upplýsingar um ákveðna pætti viðfangsefnisins, en pó vantar ítarlegar, tölulegar upplýsingar um stöðuna í heild, p.e. stöðu kynjanna í íslensku atvinnulífi, eins og pessi rannsókn veitir. Vissulega geta mælikvarðar aldrei sagt alla söguna en góðir mælikvarðar eru mjög mikilvægir ef vilji er til að vinna markvisst að pví að bæta tiltekið ástand.

Ýmislegt hefur verið gert til að jafna stöðu kynjanna og má par nefna að árið 2010 voru sampykkt lög á Íslandi um að hvort kyn skyldi vera að lágmarki 40\% í stjórnum fyrirtækja með fleiri en 50 starfsmenn (sbr. lög nr. 13/2010). Slíkar kröfur eru dæmi um markmið stjórnvalda sem stefnt er að. Undanfarin ár hefur Félag kvenna í atvinnulífinu (FKA) barist fyrir pví að fjölga konum í framkvæmdastjórnum fyrirtækja. FKA kom af stað nýju verkefni, sem kallast Jafnvægisvogin, með velferðaráðuneytinu og samstarfsaðilum úr viðskiptalífinu, með pað að markmiði að hlutfall kynja í framkvæmdastjórnum fyrirtækja verði a.m.k. 40/60 árið 2027 (Ásta Dís Óladóttir o.fl., 2019). Konur upplifa ennpá hindranir og ójöfn tækifæri kynjanna á vinnumarkaði prátt fyrir aukna áherslu á jafnrétti kynjanna í íslensku atvinnulífi (Júlíusdóttir, Rafnsdóttir og Einarsdóttir, 2018; Unnur Dóra Einarsdóttir, Erla S. Kristjánsdóttir og Póra H. Christiansen, 2017).

Staða kynjanna í íslensku atvinnulífi hefur töluvert verið rannsökuð, en viðfangsefnið er flókið og margpætt og erfitt er að henda reiður á nákvæmlega hvaða pættir geta stuðlað að og dregið úr ójafnri stöðu kynjanna í íslensku atvinnulífi. Tilgangur rannsóknarinnar er að próa skorkort sem nýtist til að fylgjast með árangrinum í pví að jafna stöðu karla og kvenna í íslensku atvinnulífi. Skorkortið byggist á viðeigandi mælikvörðum, og dregur 
fram í safni mælikvarða tölur sem gefa glögga heildarmynd af stöðu kynjanna í íslensku atvinnulífi. Par sem ein tala segir lítið, nema um mjög afmarkað efni, pá er nauðsynlegt að draga fram safn af tölum. Tölurnar mega hins vegar ekki vera of margar pví pá er erfitt að átta sig á meginatriðum og sjá heildarmynd. Ef nota á slíkt safn af tölum til að fylgjast með próun pá purfa pær að byggjast á vel skilgreindum mælikvörðum sem settir eru fram í safni mælikvarða (Martin og Sauvageot, 2011). Til að safnið gefi góða heildarmynd af stöðunni parf að flokka mælikvarðana saman. Leitað var svara við tveimur rannsóknarspurningum. Fyrri rannsóknarspurningin er: Hvaða safn mælikvarða, sett fram í jafnréttisskorkorti, gefur heildarmynd af stöðu kynjanna í íslensku atvinnulífi? Til að leggja mat á hvaða safn mælikvarða segði mest um stöðu kynjanna í íslensku atvinnulífi var nauðsynlegt að skoða tölur fyrir pá og pví var tölum frá 1999 til 2018 safnað í peim mæli sem hægt var. Pessar tölur veita greinargóðar upplýsingar og pví var sett fram önnur rannsóknarspurning: Hver er staða kynjanna í íslensku atvinnulífi samkvæmt jafnréttisskorkortinu?

Rannsókn pessi er byggðá niðurstöðum fyrri rannsóknar par sem heildarmynd er sýnd með áhrifariti af páttum sem hafa áhrif á stöðu kynjanna í íslensku atvinnulífi, sjá mynd 1 (Snjólfur Ólafsson, Erla S. Kristjánsdóttir, Lára Jóhannsdóttir og Póra H. Christiansen, 2019). Auk pess er byggt á mælikvörðum sem aðrir hafa notað til að mæla/meta afmarkaða pætti málsins. Sumir peirra koma fram í skilgreindum söfnum mælikvarða eða eru grunnur fyrir vísitölu jafnréttis, en eru ekki settir fram á heildstæðan hátt eins og hér er gert. Útgangspunktur í rannsókninni er meistararitgerð Pórunnar Sigurðardóttur (2018) sem dregur fram safn mælikvarða og má jafnvel líta á pað sem frumútgáfu af jafnréttisskorkorti.

Til pess að finna gott safn mælikvarða fyrir jafnréttisskorkortið voru ýmis söfn mælikvarða og vísitölur skoðuð. Niðurstöður peirrar vinnu eru pær að í jafnréttisskorkortinu er dregið saman safn 28 mælikvarða á stöðu kynjanna í atvinnulífinu og eru peir flokkaðir í fjóra flokka, sem eru: laun og atvinnupátttaka, völd og áhrif, náms- og starfsval, fjölskylduábyrgð. Pá voru valdir mælikvarðar á skorkortið, dregnar fram tölur fyrir pá og tölurnar ræddar stuttlega. Ekki er vitað til pess að skorkort sem petta hafi áður verið sett fram varðandi pað viðfangsefni sem fjallað er um hér, annað en pau frumdrög sem Pórunn Sigurðardóttir setti fram í sinni meistararitgerð. Jafnréttisskorkortið getur gagnast í rannsóknum til að sýna stöðu kynjanna og hvernig hún próast. Рað hefur einnig hagnýtt gildi fyrir pá sem vinna að pví að bæta stöðu kynjanna í íslensku atvinnulífi, hvort heldur er stjórnvöld eða aðilar vinnumarkaðarins.

I kafla 2 er fjallað um stöðu kynjanna í atvinnulífinu, einkum á Íslandi. Kafli 3 fjallar um aðferðafræði og er par útskýrt á hverju skorkort grundvallast, sjá mynd 2, hverjir eru helstu eiginleikar skorkorta og hvers vegna hér er farin sú leið að próa skorkort frekar en annars konar safn mælikvarða. Kafli 4 fjallar um ýmis söfn mælikvarða sem hafa verið notuð til að lýsa stöðu kynjanna. Í kafla 5 eru valdir mælikvarðar á skorkortið, dregnar fram tölur fyrir pá og stutt umræða um pær. Umræður eru síðan í kafla 6.

\section{Konur og karlar í íslensku atvinnulífi}

Á Íslandi er lögð mikil áhersla á jafnrétti og jöfn tækifæri kvenna og karla. Lög um jafna stöðu og jafnan rétt kvenna og karla (nr. 10/2008) leggja ríka skyldu á fyrirtæki um að sinna jafnréttismálum. Í 18. grein laganna (nr. 10/2008) er fjallað um réttindi og skyldur atvinnurekenda en par segir meðal annars að atvinnurekendur skuli leggja áherslu á að jafna hlut kynjanna í stjórnunar- og áhrifastöðum og stuðla að pví að störf flokkist ekki í sérstök kvenna- og karlastörf. Staða kvenna á íslenskum vinnumarkaði hefur verið talsvert í umræðunni undanfarin ár og áratugi og mælist Ísland mjög hátt í jafnréttiskönnunum (World Economic Forum, 2020). Ísland kemur einnig best út í mælingum Nordic Labour Journal á stöðu kynjanna í valdastöðum á Norðurlöndum (Gender Equality Barometer) fyrir árið 2019 og má pað helst pakka kjöri Drífu Snædal í stöðu forseta ASÍ (Lindahl, 2019). Hlutfall kvenna í hinum ýmsu áhrifastöðum í samfélaginu er engu að síður ennpá 
lægra en karla (Hagstofa Íslands, Jafnréttisstofa og forsætisráðuneytið, 2019). Misvægi kynja í æðstu stöðum er jafnframt tiltekið sem ein af peim áskorunum sem Ísland stendur frammi fyrir pegar kemur að pví að vinna að heimsmarkmiði 5 um jafnrétti kynjanna (Forsætisráðuneytið, 2019).

Konur eru í miklum meirihluta pegar kemur að háskólamenntun, en nálægt tvöfalt fleiri konur en karlar hafa útskrifast með háskólagráđu frá aldamótum (Hagstofa Íslands, 2020). Enn fremur er atvinnupátttaka kvenna sú hæsta innan OECD, en tæplega 80\% kvenna störfuðu utan heimilis árið 2018 (Hagstofa Íslands o.fl., 2019; OECD, 2019). Aftur á móti er hlutfall kvenna í stöðu framkvæmdastjóra á Íslandi rétt um 23\% pegar öll fyrirtæki eru skoðuð. Enn lægra hlutfall kvenna er í framkvæmdastjórastöðum í fyrirtækjum með yfir 100 starfsmenn eða um 12\% (Hagstofa Íslands o.fl., 2019). Árið 2010 var Ísland annað landið á heimsvísu á eftir Noregi til að̋ lögleiða kynjajafnrétti (kynjakvóta) í stjórnum fyrirtækja og sampykkt var að hvort kyn skyldi að lágmarki vera $40 \%$ í fyrirtækjum með 50 starfsmenn eða fleiri (sbr. lög nr. 13/2010). Í lok ársins 2017 var hlutfall kvenna í stjórnum peirra fyrirtækja 32,6\% (Hagstofa Íslands, 2018).

Prátt fyrir petta hafa konur staðið höllum fæti pegar kemur að stjórnunarstöðum og setu í stjórnum stærri fyrirtækja og konur upplifa enn hindranir á íslenskum vinnumarkaði hvað pennan pátt varðar prátt fyrir aukna áherslu á kynjajafnrétti og jöfn tækifæri kynjanna (Júlíusdóttir o.fl., 2018; Unnur Dóra Einarsdóttir o.fl., 2017). Varðandi launamun kynjanna, pá eru meðalatvinnutekjur karla hærri en tekjur kvenna með sömu menntun. Árið 2017 var óleiðréttur launamunur kynjanna rúmlega 15\%, en tæp 14\% ef aðeins launafólk í fullu starfi er skoðað (Hagstofa Íslands o.fl., 2019).

Lög um jafna stöðu og jafnan rétt karla og kvenna (nr. 10/2008) voru sett á Alpingi 2008 og 2018 voru sett lög um jafna meðferð á vinnumarkaði, óháð aldri, trú, fötlun o.fl. (nr. 86/2018), sem leggja bann við mismunun við ráðningu, í starfi eða í tengslum við laun og kjör. Prátt fyrir að réttur til fæðingarorlofs hafi verið jafnaður með lögum um fæðingar- og foreldraorlof sumarið 2000 (nr. 95/2000) nýta konur frekar fæðingarorlof en karlar (Velferðarráðuneytið, 2018).

Innlendar rannsóknir sýna að karlar verja meiri tíma í launaða vinnu en konur. Á móti verja konur meiri tíma í að sinna ólaunuðum heimilis- og umönnunarstörfum (Forsætisráđuneytið, 2020; Hagstofa Íslands o.fl., 2019; Katrín Ólafsdóttir og Steinunn Rögnvaldsdóttir, 2015; Kolbeinn Stefánsson, 2015; Póra Kristín Pórsdóttir og Kolbeinn Stefánsson, 2010). Í erlendum rannsóknum kemur fram að jafnvel í löndum sem standa framarlega hvað varðar kynjajafnrétti, finnst konum peim mismunað af ýmsum ástæðum á vinnumarkaði og upplifa jafnvel að pær teljist of gamlar mörgum árum áður en pær uppfylla aldursskilyrði eftirlaunaaldurs (Jyrkinen, 2013; Jyrkinen og McKie, 2012; Radl, 2012). Samkvæmt mælikvörðum Próunaráætlunar Sameinuðu pjóðanna (UNDP) á jafnrétti í heiminum hefur kynjajöfnuður aukist, en mjög hefur hægt á próuninni síðasta áratuginn og bakslags orðið vart í 15 af 31 landi sem mælingarnar náðu til (United Nations Development Programme, 2020). Stofnunin gefur út vísitöluna GSNI (Gender Social Norms Index) sem er mælikvarði sem lýsir pjóðfélagslegum viðhorfum til jafnréttis kynjanna. Vísitalan tekur til pólitískra og efnahagslegra pátta, menntamála og líkamlegra pátta og er t.d. efnahagslegi pátturinn mældur út frá staðhæfingum um að karlar hafi ríkari rétt en konur til atvinnu og að karlar séu betri stjórnendur í viðskiptum heldur en konur. Nýjustu mælingarnar sýndu að einungis 13,9 af hundraði kvenna og 9,4 af hundraði karla í heiminum hafa enga fordóma gagnvart jafnrétti kynjanna. Pó svo að Norðurlöndin komi alla jafna vel út úr jafnréttismælikvörðum og raðist oftast í topp tíu sæti lista eins og Misréttisvísitölu UNDP og vísitölu kynjabils Alpjóðaefnahagsráđsins (e. World Economic Forum Global Gender Gap Index), sýna mælingar UNDP fyrir Svípjóð að par hefur komið bakslag í próunina og bæði körlum og konum hefur fækkað sem ekki sýna neina fordóma gagnvart jafnrétti kynjanna (United Nations Development Programme, 2020). 
Vantrú á færni kvenna í viðskiptum er oft rakin til pess sem teljast kvenlægir eiginleikar eins og áhættufælni og hún talin skýra slakari rekstrarárangur fyrirtækja undir stjórn kvenna. Guðrún Johnsen (2020) bendir aftur á móti á misvísandi niðurstöður rannsókna á kynjamuni sem snúa að áhættufælni og rekstrarárangri og greinir frá niðurstöðum rannsóknar sinnar og Yu Zheng á rekstrarárangri fyrirtækja á Islandi. Ólíkt erlendum rannsóknum sýndu niðurstöður íslensku rannsóknarinnar að ekki reyndist munur á rekstrarárangri fyrirtækja eftir pví hvort pau voru undir stjórn karla eða kvenna, auk pess sem ekki reyndist munur á arðbærni, skuldsetningu, fjárhagserfiðleikum og afskriftum í rekstri fyrirtækja eftir pví hvort pau voru í meirihlutaeigu karla eða kvenna. Með pví að kanna rekstrarárangur fjölskyldufyrirtækja sem komin voru í hendur annarar kynslóðar eigenda komst rannsóknin hjá ýmsum mögulegum skekkjum og styrkir pað niðurstöðurnar um að "við getum ekki gengið að poí vísu að konur séu i eðli sínu áhættufælnari rekstraraðilar eða leiðtogar i fyrirtækjum, einfaldlega vegna pess að pær eru konur" (Guðrún Johnsen, 2020, bls. 3). Ekki eru poí rekstrarlegar skýringar á poí að færri konur en karlar stýra fyrirtækjum á Íslandi.

I grein sem ber yfirskriftina: Pættir sem hafa áhrif á stöðu kynjanna í íslensku atvinnulífi: Heildarmynd sýnd með áhrifariti (Snjólfur Ólafsson o.fl., 2019), gera höfundar grein fyrir niðurstöðum rannsóknar sem fólst einkum í átta rýnifundum með sérfræðingum og stjórnendum sem tengjast íslensku atvinnulífi. Áhrifaritið á mynd 1 sýnir efnisatriði sem dregin voru fram viðúrvinnslu gagna frá rýnihópafundunum. Hvert efnisatriði er fulltrúi fyrir safn atriða sem fela í sér svipaða hugsun. Efnisatriðin eru orðuð pannig að áhrifin sem dregin eru fram á milli peirra eru í öllum tilvikum jákvæð, p. e. fela í sér að stuðlað er аð jákvæðum breytingum. Petta áhrifarit er notað hér sem útgangspunktur við pað verkefni að skilgreina safn mælikvarða fyrir stöðu kynjanna í atvinnulífinu. Í flestum tilvikum voru áhrifin sem örvarnar lýsa nefnd á rýnifundum, oft af mörgum pátttakendum. Ekki er reynt að sýna öll áhrif með örvum heldur er dregið fram pað sem telja má mikilvæg tengsl.

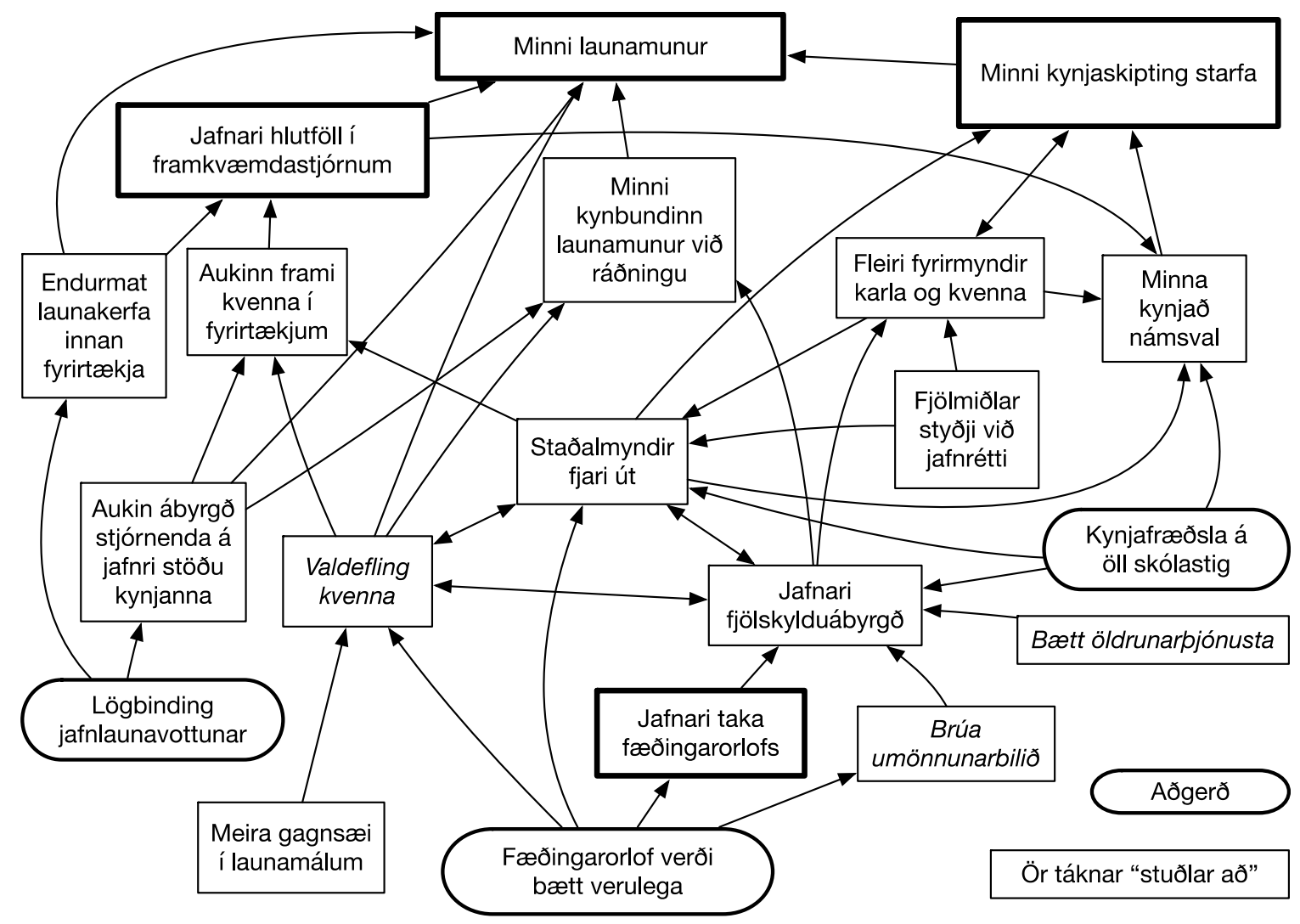

Mynd 1. Áhrifarit sem sýnir heildarmynd viðfangsefnisins: Hvaða pættir geta stuðlað að jafnri stöðu kynjanna í íslensku atvinnulífi? (Snjólfur Ólafsson o.fl., 2019, bls. 79). 
Á hverjum rýnifundi var sérstaklega rætt um mögulega mælikvarða fyrir atriðin sem höfðu komið fram á fundinum og kom pá mjög vel í ljós hvað pað er erfitt að mæla flest atriðin. Sumt er erfitt að sjá fyrir sér að hægt sé að mæla, t.d. valdefling kvenna eða staðalmyndir fjari út, pó svo að óbeinir pættir gætu par haft áhrif eins og jafnari hlutföll í framkvæmdastjórnum, fjölmiðlaumræða og kynjafræðsla á öllum skólastigum. Ein af ályktunum rannsakenda eftir rýnifundina var að líklega væri einna auðveldast að skilgreina og velja mælikvarða fyrir fjögur efnisatriði sem eru auðkennd með sverari ferhyrndum römmum. Við leit að mælikvörðum á jafnréttisskorkortið er horft á áhrifaritið í heild en nokkur áhersla lögð á pessi fjögur atriði. Auk pess er farið í kafla 4 yfir önnur söfn mælikvarða sem gætu gagnast við próun jafnréttisskorkortsins.

\section{Aðferðafræði}

Eins og fram hefur komið er markmið rannsóknarinnar að draga fram safn mælikvarða, p.e. jafnréttisskorkort, sem gefur heildarmynd af stöðu kynjanna í íslensku atvinnulífi og meta stöðuna. Í skýrslu Menningarmálastofnunar Sameinuðu pjóðanna, UNESCO, nánar tiltekið Tölfræðistofnunar UNESCO (e. UNESCO Institute for Statistics), er gerð grein fyrir próun skorkorta fyrir æðri menntun (Martin og Sauvageot, 2011). Byggt á peirri umfjöllun má draga fram mynd 2 sem sýnir próunarferil skorkorta allt frá pví að stefnumarkmið eru sett. Fremst er stefnumarkmið stjórnvalda, t.d. pað að jafna stöðu kynjanna í atvinnulífinu. Til pess að ná pví markmiði parf að afla viðeigandi gagna, t.d. tölulegra gagna. Síðan má nota tölfræðileg tól, svo sem prósentur, tíðni, hlutföll, eða vísitölur til pess að sýna stöðuna. Í framhaldinu er hægt að setja fram lykilmælikvarða (e. key performance indicators eða KPIs). Pessa mælikvarða er síðan hægt að draga saman í söfn mælikvarða (e. indicator systems), s.s. skorkort eða mælaborð sem notuð eru til að meta árangur. Pær niðurstöður má síðan nýta til að bæta mælikvarða og tölfræðileg tól, stuðla að betri gögnum og meta hvort að stefnumarkmiðunum hafi verið náð. Rætt verður nánar um vísitölur, lykilmælikvarða og söfn mælikvarða hér að neðan.

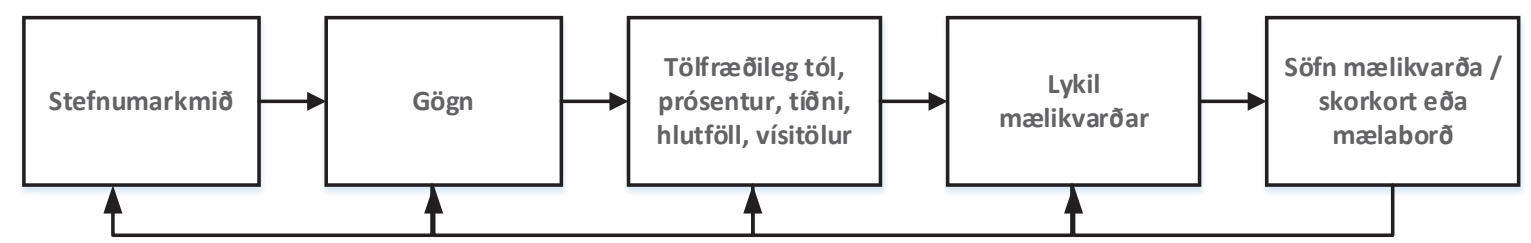

Mynd 2. Próunarferill frá stefnumarkmiðum til skorkorta (Martin og Sauvageot, 2011).

Vísitölur byggja á meðaltölum sem fengin eru með pví að vega saman tilteknar stærðir til að setja fram eina tölu. Vísitölur er mikið notaðar á sviði efnahagsmála, t.d. launavísitala, vísitala neysluverðs, eða verðlagsvísitölur. mismunandi landa á samanburðarhæfan hátt og hefur slíkur samanburður leitt í ljós að jafnrétti er komið lengra á Íslandi en í öðrum löndum heimsins ef marka má vísitölu kynjabils Alpjóðaefnahagsráðsins (World Economic Forum, 2020) sem rætt er um í kafla 4.2. Slík vísitala sýnir einnig hvort að staðan próast í rétta átt eða ranga sé horft á breytingar á milli tímabila. Vísitölur fela aftur á móti í sér of mikla einföldun til að unnt sé að draga miklar ályktanir, t.d. gæti staða jafnréttis versnað varðandi eitt atriði sem liggur til grundvallar vísitölunni en batnað varðandi annað en vísitalan gefið sömu tölu. Pær veita einnig takmarkaðar upplýsingar um pað hvernig æskilegt er að vinna að úrbótum, til pess parf frekari sundurliðun á undirliggjandi páttum sem gera má með skorkorti. Einnig hefur verið bent á að prátt fyrir að Ísland skori hátt á ýmsum mælikvörðum um jafnrétti kynjanna pá er hér ennpá verk að vinna og að slíkir mælikvarðar gefi oft prönga og einfaldaða mynd af kynjajafnrétti, jafnvel villandi mynd (Einarsdóttir, 2020).

Lykilmælikvarðar, stundum kallaðir árangursmælikvarðar, byggjast á undirliggjandi 
gögnum sem greind hafa verið með tölfræðilegum tólum, svo sem prósentum, hlutföllum eða vísitölum. Peir draga saman talsvert magn af gögnum, en tilgangurinn er að setja fram yfirlit eða almennar vísbendingar um ástand sem verið er að greina og nýtast pví til að ákvarða stöðu, fylgjast með próun og framförum, mæla styrkleika eða veikleika og kynna árangur. Með pví að tengja mælikvarða við aðra mælikvarða, aðrar vísbendingar, sem settir eru fram í safni mælikvarða eða skorkorti má ná fram allsherjargreiningu á tilteknu kerfi. Slíkt ætti að hjálpa til að draga fram hver vandamálin eru, auðvelda mælingu á peim og vinna að úrbótum (Martin og Sauvageot, 2011).

Pegar próa á jafnréttisskorkort er mikilvægt að líta til jafnréttisvísitalna sem og safna lykilmælikvarða, sjá mynd 2 og kafla 4 . Vel hefði verið hægt að leggja til vísitölu fyrir stöðu kynjanna í atvinnulífinu, en slíkt er ekki gert í pessari rannsókn par sem meginkostur og megingalli vísitalna felst í einfaldleika peirra (ein tiltekin tala). Byggt á hugmyndafræði um stefnukort, skorkort, lykilmælikvarða og söfn mælikvarða eða frammistöðumælaborð, er í næstu köflum dregið fram á skipulegan hátt safn mælikvarða, byggt á áhrifariti, fyrirliggjandi gögnum og söfnum mælikvarða, sem endurspegla stöðu kynjanna í íslensku atvinnulífi og pannig próað jafnréttisskorkort fyrir íslenskt atvinnulíf.

Í stefnumiðuðu árangursmati (e. Balanced Scorecard) byggist skorkort (e. scorecard) gjarnan á stefnukorti (e. strategy map) sem á að gefa heildarmynd af stefnunni sem skorkortið á að mæla (Snjólfur Ólafsson, 2005). Mynd 2 sýnir að skorkort getur einnig grundvallast á stefnumarkmiðum, t.d. stefnu stjórnvalda. Segja má að slíkt stefnukort liggi pegar fyrir í formi áhrifaritsins sem sýnt er í mynd 1 og rætt er um í greininni bættir sem hafa áhrif á stöðu kynjanna i íslensku atvinnulífi: Heildarmynd sýnd með áhrifariti (Snjólfur Ólafsson o.fl., 2019), en par eru dregin fram ýmis mikilvæg atriði stefnunnar og áhrif peirra hvert á annað. Í tengslum við stefnukortið/áhrifaritið er, í pessari grein, farin sú leið að próa skorkort í anda stefnumiðaðs árangursmats (Kaplan og Norton, 2001a; Lawrie og Cobbold, 2004; Rigby, 2001, 2003) í pví skyni að mæla kynjajafnrétti, en pað byggir á pví að finna tölur og mælikvarða sem gefa hvað gleggsta heildarmynd af stöðunni. Hér á eftir er fjallað um eðli og eiginleika skorkorta og síðan rökstutt hvers vegna skorkort varð fyrir valinu við að mæla kynjajafnrétti í íslensku atvinnulífi.

Upphaflega var stefnumiðað árangursmat sett fram sem stjórntæki fyrir hagnaðardrifin fyrirtæki (Rigby, 2001, 2003) en að hefur síðan verið notað hjá alls kyns skipulagsheildum, meðal annars hjá stjórnvöldum, stofnunum og sveitarfélögum (Khalid, Beattie, Sands og Hampson, 2019; Mendes, Nunes og Teixeira, 2014; Ndevu og Muller, 2018; Wisniewski og Ólafsson, 2004). Skorkort hafa einnig verið próuð sérstaklega til pess að ná fram kynjajafnrétti hjá einstökum fyrirtækjum (Wijk, 2007) eða stofnunum, eins og Sameinuðu pjóðunum (OSAGI og OFPW, 2010), en ekki fyrir atvinnulífið í heild sinni eins og gert er í pessari grein. Greina má prjár kynslóðir skorkorta, par sem upphaflega útgáfan frá Kaplan og Norton (Kaplan og Norton, 2001a) telst til fyrstu kynslóða skorkorta, í annarri útgáfu komu fram endurbætur og sterkari tengsl við stefnumótandi markmið (e. strategic goals) og í peirri priðju sterkari tengsl við árangurstjórnun, aðferðir (tól) og stuðningsnet (Lawrie og Cobbold, 2004).

Samkvæmt Lawrie og Cobbold (2004) eru helstu eiginleikar skorkorta: 1) blanda af fjárhagslegum og annars konar mælikvörðum, 2) takmarkaður fjöldi mælinga (t.d. 15-25), 3) flokkar (klasar) mælikvarða sem í tilfelli fyrirtækja nefnast oft fjárhagur, viðskiptavinir, innri ferlar, lærdómur og nýsköpun eða lærdómur og vöxtur, 4) mælikvarðar sem tengjast stefnumótandi markmiðum, 5) stuðningur æðstu stjórnenda við val á mælikvörðum sem pannig endurspeglar forgangsröðun peirra og 6) orsakasamhengi á milli aðgerða í skorkortinu sem og afturvirkra (e. lag) og framvirkra (e. lead) mælikvarða (Kaplan og Norton, 1992, 1993, 1996a, 1996b, 2001b). Skorkort eru einnig tengd við framtíðarsýn (e. vision), hlutverk (e. mission) og markmið (e. objective) fyrirtækja (Syalom, 2015). Hvert fyrirtæki velur safn mælikvarða fyrir sitt skorkort sem á að endurspegla lykilatriði í stefnu pess.

Náskylt skorkorti er pað sem gjarnan kallast mælaborð (e. dashboard) (Shamsuzzoha, 
Hao, Helo og Khadem, 2014), einnig nefnd mælaborð fyrirtækis (e. corporate dashboard), mælaborð stjórnandans (e. management dashboard) eða frammistöðumælaborð (e. performance dashboard). Pó svo að mismunandi heiti séu notuð yfir mælaborðin, pá eru pau í eðli sínu svipuð, en pau byggja á pví að tengja saman viðskiptagreind (e. business intelligence) og frammistöðustjórnun (e. corporate performance management) (Melchert, Winter og Klesse, 2004) með pví að safna og greina gögn á pann hátt að úr peim verði aðgengilegar upplýsingar, oft settar fram á myndrænan hátt, sem nýtast til að bæta frammistöðu skipulagsheildar (Kristín Guðmundsdóttir og Eðvald Möller, 2012; Shamsuzzoha o.fl., 2014). Í pessu skyni eru notaðir lykilmælikvarðar sem stuðla að skjótri ákvarðanatöku sem byggist á nýjustu upplýsingum og gögnum (Mack, 2014). Par sem tölurnar í mælaborði eru fengnar með vel skilgreindum mælikvörðum pá eru tölurnar samanburðarhæfar við eldri tölur og pannig auðvelt að fylgjast með próun mála. Mælaborðin eru yfirleitt útfærð pannig að hægt er að sjá marga mælikvarða í einu en líka er hægt að kafa ofan í einstaka mælikvarða og t.d. sjá undirmælikvarða. Ólíkt skorkortum, pá er breytilegt hvaða safn mælikvarða notandandinn horfir á hverju sinni pví mælaborð gera notendum kleift að grúska í gagnagrunni. Segja má að Jafnvægisvog Félags kvenna í atvinnulífinu (FKA, e.d.-a) sé dæmi um mjög einfalt mælaborð, sjá nánar í kafla 4.6.

Í skýrslu UNESCO (Martin og Sauvageot, 2011, bls. 31) er sýnt hvernig próa má skorkort í tíu skrefum, sem tengja má við mynd 2, en pau eru:

1. Afmarka eða skilgreina markmið, sem í pessu tilviki er að jafna stöðu kynjanna í atvinnulífinu.

2. Búa til lista stefnumála sem byggjast á markmiðunum, en segja má að slíkt komi fram í áhrifaritinu á mynd 1.

3. Búa til lista yfir mögulega mælikvarða.

4. Tilgreina pau gögn sem parf til að reikna út mælikvarðana.

5. Finna tiltæk gögn.

6. Reikna gildi mælikvarðanna.

7. Sannreyna niðurstöður.

8. Greina mælikvarðana.

9. Velja endanlega mælikvarða á skorkortið.

10. Ákveða birtingarform (e. layout) skorkortsins.

Próun jafnréttisskorkortsins fylgir pessum skrefum í grófum dráttum. Við pað má pó bæta að dregnir eru fram mælikvarðar á skorkortið með pví að ákveða fyrst flokka mælikvarða og síðan velja nokkra mælikvarða í hverjum flokki.

\section{Söfn mælikvarða á stöðu jafnréttismála}

Í pessum kafla er fjallað um helstu söfn mælikvarða varðandi jafnrétti sem geta nýst við að ákveða pá flokka mælikvarða sem verða á skorkortinu og að velja einstaka mælikvarða skorkortsins. Вyrjað er á að fjalla um alpjóðleg söfn mælikvarða, en síðan er fjallað um íslensk söfn. Pau söfn og vísitölur sem rætt er um eru; Heimsmarkið Sameinuðu pjóðanna, Vísitala kynjabils, EIGE, CORE skorkortið, Jafnréttisskorkort Ástralíu, Mælaborð Jafnvægisvogar FKA, flokkar og mælikvarðar úr bæklingnum Konur og karlar á Íslandi og að lokum mælitæki Pórunnar Sigurðardóttur. Í hverjum undirkafla er gerð grein fyrir einu tilteknu safni, eða vísitölu, hvaða aðilar standa að pví, hvaða flokkar eru skilgreindir beint eða óbeint og sagt frá helstu mælikvörðum sem eru taldir mikilvægir fyrir pessa rannsókn. Að lokum eru dregnar ályktanir varðandi pað hvernig viðkomandi safn nýtist við gerð jafnréttisskorkorts. 


\subsection{Heimsmarkmið Sameinuðu pjóðanna}

Heimsmarkmið Sameinuðu pjóðanna sem sett voru fram árið 2015 fela í sér markmið um sjálfbæra próun sem ná á eigi síðar en árið 2030. Markmiðin eru alls 17, sjá mynd 3, en undirmarkmið eru 169 („Heimsmarkmiðin um sjálfbæra próun“, e.d.). Til pess að meta árangur af innleiðingu heimsmarkmiðanna á samræmdan hátt á milli pjóða eru 232 mælikvarðar lagðir til grundvallar, par af liggur fyrir skilgreind aðferðafræði fyrir 164 mælikvarða (Stjórnarrád Íslands, e.d.-a). Reyndar eru sumir mælikvarðarnir ekki tölulegir heldur eru sett fram markmið sem er fylgst með hvort hafi náðst eða ekki.

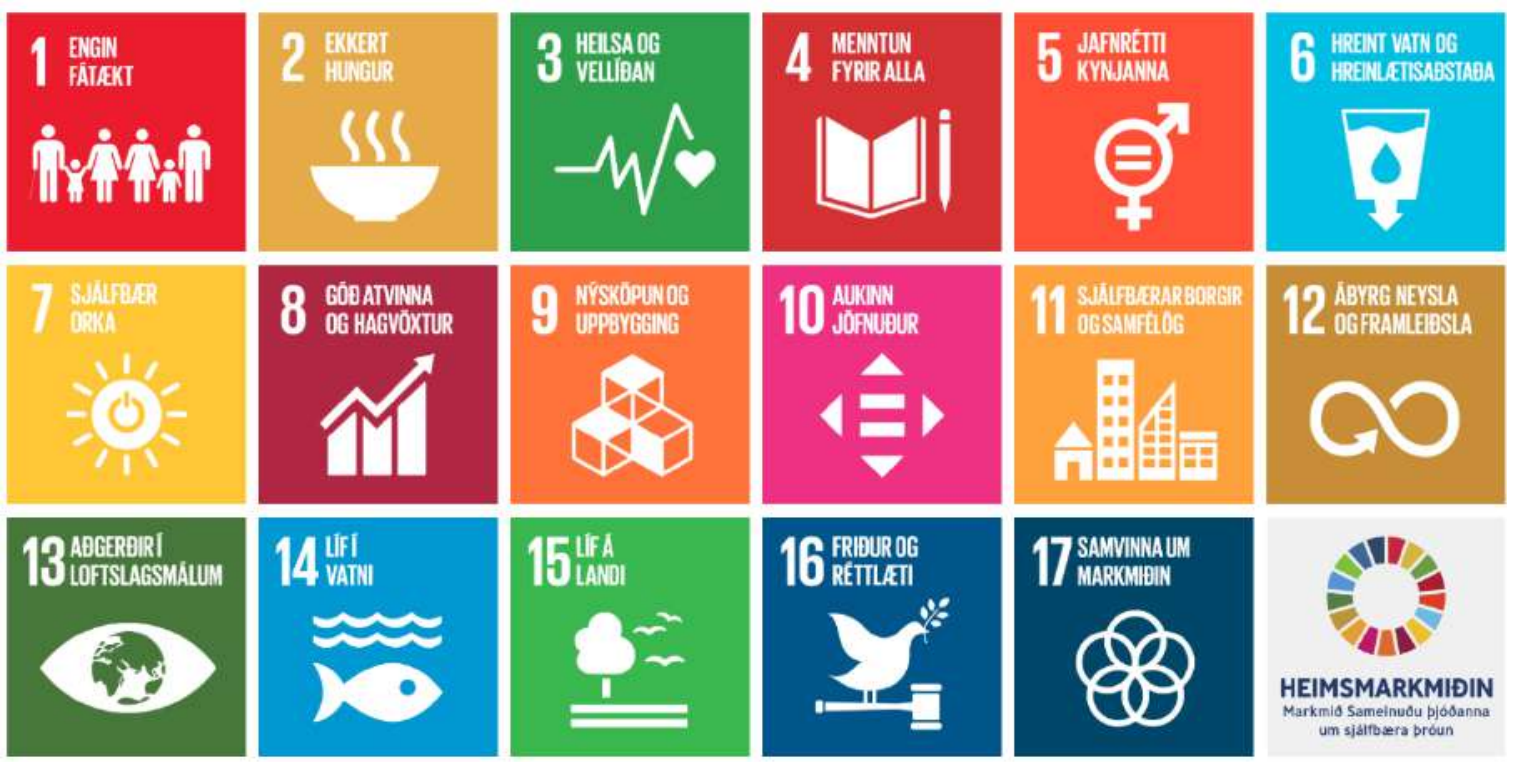

Mynd 3. Heimsmarkmið Sameinuðu pjóðanna um sjálfbæra próun (Félag Sameinuðu pjóðanna á Íslandi, e.d.).

Markmið 5 fjallar um jafnrétti kynjanna, eins og sjá má á mynd 3. Undir pað falla níu undirmarkmið, mæld með 14 mælikvörðum. Par af liggja fyrir gögn um sex mælikvarða á Íslandi (Stjórnarráð Íslands, e.d.-b). Tveir mælikvarðar par sem gögnum er safnað koma sérstaklega til álita varðandi skorkort um jafnrétti í atvinnulífinu og einn par sem gögnum er ekki safnað af stjórnvöldum, sjá töflu 1.

Tafla 1. Flokkar og mælikvarðar heimsmarkmiða Sameinuðu pjóðanna (Stjórnarráð Íslands, e.d.-b).

\begin{tabular}{lc}
\hline Flokkur & Mælikvarðar \\
\hline $\begin{array}{l}\text { Ólaunuð umönnunar- og } \\
\text { heimilisstörf }\end{array}$ & $\begin{array}{c}5.4 .1: \text { Hlutfall tíma sem varið er til ólaunaðra heimilis- og umönnunarstarfa, eftir } \\
\text { kyni, aldri og staðsetningu. }\end{array}$ \\
\hline $\begin{array}{l}\text { Virk pátttaka og jöfn tækifæri } \\
\text { kvenna }\end{array}$ & $\begin{array}{l}5.5 .1: \text { Hlutfall kvenna a) á pjóðpingum og b) í sveitarstjórnum. } \\
5.5 .2: \text { Hlutfall kvenna í stjórnunarstöðum. }\end{array}$ \\
\hline
\end{tabular}

Petta eru í raun ekki prír mælikvarðar heldur prjú söfn af mælikvörðum. Hver mælikvarði, í peim skilningi pess orðs sem á við í pessari grein, gefur eina tölu á hverju tímabili, sem er ár í okkar tilviki. Mælikvarði 5.5.1 er safn tveggja mælikvarða, svo dæmi sé tekið, annar hlutfall kvenna á pjóðpingi og hinn hlutfall kvenna í sveitarstjórnum. Ýmsir mælikvarðar í hinum söfnunum sem fjallað er um í pessum kafla eru einnig söfn af mælikvörðum.

Fjölskylduábyrgð hefur mikil áhrif á kynjahalla í atvinnulífinu og pví mikilvægt að vera með einhverja mælikvarða um pað í skorkortinu, en fjölskylduábyrgð endurspeglast m.a. í ólaunuðum umönnunar- og heimilisstörfum. Hvað mælikvarða 5.4.1 varðar pá kemur 
fram á vef Stjórnarráðsins (e.d.-b) að pað liggi ekki fyrir almennar upplýsingar um hann en vísað er í skýrslu Katrínar Ólafsdóttur og Steinunnar Rögnvaldsdóttur (2015) ásamt könnun um vinnu aðstandenda fatlaðs fólks. Mælikvarði 5.5.1 um hlutfall kvenna á pjóðpingum og í sveitarstjórnum pykir einnig skipta máli, en deila má um pað hvort Alpingi og sveitarstjórnir séu hluti af íslensku atvinnulífi. Í ljósi pess að Alpingi og sveitarstjórnir hafa mikil áhrif á íslenskt atvinnulíf er sá mælikvarði tiltekinn sem mögulegur mælikvarði í skorkorti um stöðu jafnréttis í íslensku atvinnulífi. Samkvæmt Stjórnarráði Íslands (e.d.-b) er upplýsingum um mælikvarða 5.5.2 ekki safnað af stjórnvöldum, en verið að kanna fýsileika pess að greina stöðu hans líka. Reynar birtir Hagstofa Íslands upplýsingar um hlutfall kvenna í stjórnunarstöðum og mælikvarðar 2.4 og 2.5 í jafnréttisskorkortinu eru slíkir mælikvarðar.

\subsection{Vísitala kynjabils}

Vísitala kynjabils er vísitala sem Alpjóðaefnahagsráđið birtir árlega, allt frá árinu 2006, og er ætlað að mæla kynjajafnrétti (World Economic Forum, 2020). Vísitalan er vegið meðaltal vísitalna (e. subindexes) fjögurra flokka sem mæla kynjabil og er hæsta fáanlega vísitalan 1, en pá er búið að jafna út kynjabilið í öllum fjórum flokkunum (Gná Guðjónsdóttir, 2017; World Economic Forum, 2020). Mælikvarðar sem liggja til grundvallar Vísitölu kynjabilsins eru sýndir í töflu 2.

Tafla 2. Flokkar og mælikvarðar í vísitölu kynjabilsins (World Economic Forum, 2020).

\begin{tabular}{ll}
\hline Flokkur & Mælikvarðar \\
\hline Atvinnupátttaka og jöfn tækifæri & Atvinnupátttaka eftir kyni. \\
& Sömu laun fyrir sambærileg og jafnverðmæt störf. \\
& Áætlaðar tekjur. \\
& Löggjafarpingmenn, æðstu embættismenn og stjórnendur. \\
& Fagmenn og tæknilegir starfsmenn. \\
\hline Menntunarstig & Hlutfall læsis. \\
& Innritun í grunnskóla. \\
& Innritun í framhaldsskóla. \\
& Innritun í háskóla. \\
\hline Heilsa og lífslíkur & Kynjahlutfall við fæðingu. \\
& Heilbrigðar lífslíkur í árum. \\
\hline Pólitísk valdefling & Pingkonur. \\
& Konur í ráðherraembætti. \\
& Árafjöldi með kven-/karlkyns pjóðhöfðingja (á síðustu 50 árum). \\
\hline
\end{tabular}

Undir flokknum atvinnupátttaka og jöfn tækifæri eru fimm undirpættir: atvinnupátttaka kvenna miðað við atvinnupátttöku karla, launajafnrétti kvenna og karla fyrir sambærileg störf, áætlaðar tekjur kvenna sem hlutfall af tekjum karla, hlutfall kvenna samanborið við hlutfall karla hvað varðar löggjafarvald, æðstu embættismenn og stjórnendur í atvinnulífinu. Menntunarstig felur í sér fjóra undirpætti sem eru læsi kvenna samanborið við læsi karla sem og innritunarhlutfall kvenna í grunn-, framhalds- og háskólum, samanborið við innritunarhlutfall karla. Heilsa og lífslíkur felur í sér tvo undirpætti, en peir eru kynjahlutfall við fæðingu og heilbrigði og lífslíkur kvenna samanborið við sömu pætti hjá körlum. Prír pættir falla undir pólitíska valdeflingu: hlutfall kvenna á pingi samanborið við hlutfall karlpingmanna, kvenráðherrar samanborið við karlráðherra og fjöldi ára sem kvenpjóðhöfðingjar hafa verið við völd, samanborið við karla (World Economic Forum, 2020).

Peir mælikvarðar sem falla undir Vísitölu kynjabilsins eiga misvel við íslenskar aðstæður, auk pess sem peir hafa mismikla pýðingu fyrir stöðu kynjanna í íslensku atvinnulífi. Fyrsti flokkurinn á að sjálfsögðu heima á jafnréttisskorkorti fyrir íslenskt atvinnulíf, og sá síðasti getur líka átt heima par. Hinir tveir flokkarnir segja meira um stöðuna í próunar- 
löndum, en fyrir Îsland er pað helst kynbundið námsval sem á erindi á jafnréttisskorkort.

\subsection{Jafnréttisvísitala EIGE}

Evrópska jafnréttisstofnunin (European Institute for Gender Equality, EIGE) hefur próað og sett fram jafnréttisvísitölu (e. gender equality index) sem er ætlað að mæla stöðu og próun jafnréttismála í Evrópu. Ísland er ekki hluti af EIGE tölfræðinni en upplýsingar um marga pessa mælikvarða eru pó til. Í vísitölunni eru sjö (yfir)flokkar og 31 mælikvarði, ásamt pví að hægt er að greina upplýsingar eftir ýmsum bakgrunnsbreytum eins og aldri, fötlun, menntunarstigi, fæðingarlandi og fjölskylduaðstæðum. Vísitalan byggir á stefnu Evrópusambandsins í jafnréttismálum og tekur til 28 landa Evrópusambandsins. Vísitalan hefur verið birt á tveggja ára fresti síðan árið 2013 (European Institute for Gender Equality, e.d.). Árið 2019 var lögð sérstök áhersla á að mæla jafnvægi milli vinnu og einkalífs (EIGE, 2019). Yfirlit yfir flokka, undirflokka og mælikvarða jafnréttisvísitölunnar má sjá í töflu 3.

Tafla 3. Mælikvarðar sem jafnréttisvísitala Evrópusambandsins byggist á (European Institute for Gender Equality, e.d.).

\begin{tabular}{|c|c|c|}
\hline Yfirflokkur & Undirflokkur & Mælikvarðar (stikkorð) \\
\hline \multirow[t]{2}{*}{ Atvinna } & Pátttaka & Atvinnupátttaka, starfsævi. \\
\hline & $\begin{array}{l}\text { Kynjaskipting starfa og gæði } \\
\text { starfa }\end{array}$ & $\begin{array}{l}\text { Starfsval, hlutfall í heilbrigðis- og félagsstarfi, sveigjanleiki í starfi, } \\
\text { starfshorfur. }\end{array}$ \\
\hline \multirow[t]{2}{*}{ Fjárhagur } & Tekjuöflun & Laun, tekjur, hagnaður. \\
\hline & Fjárhagsleg staða & Fátækt, tekjudreifing. \\
\hline \multirow[t]{2}{*}{ Pekking } & Öflun pekkingar & Pátttaka, brautskráningar. \\
\hline & Kynjaskipting & Brautskráningar úr framhaldsnámi eftir sviði. \\
\hline \multirow[t]{2}{*}{ Tími } & Umönnunarstörf & $\begin{array}{l}\text { Einstaklingar sem sinna ólaunuðum heimilis- og } \\
\text { umönnunarstörfum daglega. }\end{array}$ \\
\hline & Félagsstörf & Pátttaka í ípróttum, félagsstörfum og sjálfboðastarfi. \\
\hline \multirow[t]{3}{*}{ Völd } & Stjórnmál & Ráðherrar, pingmenn, sveitarstjórnir. \\
\hline & Efnahagur & $\begin{array}{l}\text { Stjórnarmenn í stórum fyrirtækjum, framkvæmdastjórnum, } \\
\text { bankaráði, seðlabanka. }\end{array}$ \\
\hline & Félagslegt & $\begin{array}{l}\text { Stjórnarmenn í rannsóknarstofnunum, ríkisreknum fjölmiðlum, } \\
\text { ípróttasamböndum. }\end{array}$ \\
\hline \multirow[t]{3}{*}{ Heilsa } & Staða & $\begin{array}{l}\text { Eigið mat á heilsu, lífslíkur, lífslíkur við góða heilsu, reyklausir, } \\
\text { drekkur ekki í óhófi. }\end{array}$ \\
\hline & Hegðun & Hreyfing og mataræði. \\
\hline & Aðgengi & $\begin{array}{l}\text { Aðgengi að heilbrigðispjónustu. Hefur neitað sér um læknispjónustu } \\
\text { eða tannlæknapjónustu. }\end{array}$ \\
\hline \multirow[t]{3}{*}{ Ofbeldi } & Algengi & Líkamlegt og kynferðislegt ofbeldi. Morð. \\
\hline & Alvarleiki & Heilsufarslegar afleiðingar v. ofbeldis. Fjöldi gerenda. \\
\hline & Annað & Kynferðisleg áreitni, heimilisofbeldi, mansal. \\
\hline
\end{tabular}

Fyrstu fimm flokkarnir eiga erindi á jafnréttisskorkortið, en ekki síðustu tveir, um heilsu og ofbeldi.

\subsection{CORE skorkortið}

Norska rannsóknarstofnunin um kynjajafnrétti (CORE - Centre for Research on Gender Equality) hefur frá árinu 2016 birt skorkort um stöðu jafnréttismála í atvinnulífinu. Verkefnið ber heitið CORE Norwegian Gender Balance Scorecard og var sett á laggirnar fyrir tilstuðlan jafnréttis- og barnamálaráðuneytisins í Noregi. Skorkortið er uppfært og birt á 
tveggja ára fresti (CORE - Centre for Research on Gender Equality, 2018). Tilgangur skorkortsins er að draga upp mynd af kynjahlutfalli í stjórnum og æðstu stjórnunarstöðum í norsku atvinnulífi. Mælikvarðarnir byggjast allir á upplýsingum um 200 stærstu fyrirtæki Noregs, sjá töflu 4.

Tafla 4. Flokkar og mælikvarðar í norska CORE skorkortinu (CORE - Centre for Research on Gender Equality, 2018).

\begin{tabular}{ll}
\hline Flokkur & Mælikvarðar \\
\hline Kynjajafnrétti í 200 stærstu & 1.1 Hlutfall kvenna í stjórnum. \\
fyrirtækjum & 1.2 Hlutfall kvenna meðal framkvæmdastjóra (CEO). \\
& 1.3 Hlutfall kvenna í framkvæmdastjórn. \\
& pau famanburður á kynjahlutföllum stjórna og framkvæmdastjórna eftir pví hvort \\
& päg um kynjahlutföll. \\
\hline Línu- og stoðdeildastjórnendur & 2.1 Kynjahlutföll í mismunandi stöðum innan fyrirtækja (línu, stoðdeilda, annað). \\
\hline Hægar breytingar & 3.1 Kynjahlutföll nýrra framkvæmdastjóra frá árinu 2016. \\
& 3.2 Kynjahlutföll framkvæmdastjóra sem hafa verið minna en fimm ár í starfi. \\
& 3.3 Kynjahlutföll í stjórnum og línustöðum eftir atvinnugreinum. \\
\hline Í átt að jafnrétti & 4.1 Kynjahlutföll í framkvæmdastjórnum og meðal stjórnarformanna, eftir árum. \\
& 4.2 Hlutfall fyrirtækja með jafnt kynjahlutfall í framkvæmdastjórn. \\
\hline
\end{tabular}

Allir mælikvarðarnir á pessu skorkorti koma til álita við gerð jafnréttisskorkorts fyrir íslenskt atvinnulíf. Pað eru pó einungis aðgengileg gögn fyrir suma peirra, t.d. hefur gögnum ekki verið safnað á Íslandi fyrir mælikvarða 2.1.

\subsection{Jafnréttisskorkort Ástralíu}

Jafnréttisstofnun vinnumarkaðarins (Workplace Gender Equality Agency, WGEA) er lögboðin stofnun ástralskra stjórnvalda og er starfrækt samkvæmt lögum um kynjajafnrétti á vinnumarkaði í Ástralíu frá árinu 2012 (Workplace Gender Equality Act, 2012)2012. Stofnunin hefur pað hlutverk að stuðla að jafnrétti á vinnumarkaðnum („About the Agency“, e.d.). Hún safnar árlega gögnum frá fyrirtækjum um stöðu jafnréttismála á vinnumarkaðnum. Enda pó stofnunin tali um „Australia's gender equality scorecard“ (e.d.) pá er um gagnasafn að ræða en ekki skorkort í peirri merkingu sem lýst er í kafla 3. Gögnin eru flokkuð í sex flokka (Gender equality indicators) og undir hverjum flokki eru nokkrar mælingar („WGEA Data“, e.d.). Flokkarnir sex eru:

- Kynjasamsetning vinnuafls/starfsmanna

- Kynjasamsetning stjórnenda og stjórna

- Launa- og kjarajafnrétti

- Fjölskylduvænar stefnur og aðgerðir

- Samráð við starfsfólk hvað varðar kynjajafnrétti

- Annað sem ráðherra ákveður: Kynbundin áreitni og mismunun

Atvinnurekendur í einkarekna geiranum með yfir eitt hundrað starfsmenn skulu fylla út og skila inn árlegri skýrslu til stofnunarinnar (Workplace Gender Equality Agency, 2019)2019. Í skýrslunni skal meðal annars koma fram starfaskipting og kynjasamsetning vinnustaðarins ásamt pví að tilgreina hvar vinnustaðurinn stendur á fyrirfram tilgreindum mælingum. Atvinnurekendur fylla út spurningalista sem samanstendur af 17 spurningum sem tengjast stefnumótun (e. strategy), reglum/stefnum (e. policies), frampróun starfsmanna, stjórnun, samráði við starfsfólk, hvort stutt sé við fjölskylduvænar aðgerðir eins og sveigjanlegt vinnufyrirkomulag og hvort til staðar séu stefnur og aðgerðaáætlanir 
varðandi kynbundna áreitni eða heimilisofbeldi („Guide to reporting under the Workplace Gender Equality Act 2012“, e.d.)e.d..

Gagnasafnið, sem er opinbert, tekur til yfir tæplega 5000 skipulagsheilda og yfir fimm milljón starfsmanna (um 40\% af vinnuafli). Markmiðið er að hafa jákvæð áhrif á jafnrétti á vinnumarkaði og hvernig atvinnurekendur nálgast viðfangsefnið (Workplace Gender Equality Agency, 2019)2019. Gagnasafnið er fremur yfirgripsmikið. Hægt er að bera saman niðurstöður eftir stærð skipulagsheilda og niður á atvinnugreinar og einstaka fyrirtæki. Í gagnasafninu eru bæði tölulegar mælingar (eins og kynjahlutföll) en einnig er greint frá eigindlegum gögnum (eins og hvort tiltekin stefna sé til staðar) („WGEA Data“, e.d.). Jafnréttisstofnunin birtir árlega helstu niðurstöður í svokölluðu Jafnréttisskorkorti (,Australia's Gender Equality Scorecard“, e.d.).

Tafla 5.

\begin{tabular}{|c|c|}
\hline Flokkur & Mælikvarðar \\
\hline $\begin{array}{l}\text { Reglur og stefnur (e. } \\
\text { policies and strategies) }\end{array}$ & $\begin{array}{l}\text { Eru til staðar stefnur varðandi t.d. kynjajafnrétti, ráðningar og stöðuhækkanir. } \\
\text { Frammistöðumælingar hvað varðar jafnréttismál. }\end{array}$ \\
\hline $\begin{array}{l}\text { Kynjasamsetning } \\
\text { vinnuafls }\end{array}$ & $\begin{array}{l}\text { Kynjasamsetning stjórnenda (eftir stöðu/starfsheiti). } \\
\text { Kynjasamsetning almenns starfsfólks (eftir starfsheiti). } \\
\text { Vinnuhlutfall (fullt starf, hlutastarf, annað ráðningarfyrirkomulag). } \\
\text { Kynjahlutföll peirra sem fá stöðuhækkun (stjórnendur og almennt starfsfólk). } \\
\text { Kynjahlutföll peirra sem er sagt upp (stjórnendur og almennt starfsfólk). }\end{array}$ \\
\hline $\begin{array}{l}\text { Kynjasamsetning } \\
\text { yfirstjórnar }\end{array}$ & $\begin{array}{l}\text { Vinnuveitandi hefur sett sér markmið varðandi kynjasamsetningu stjórnenda og } \\
\text { stjórnarmamma. }\end{array}$ \\
\hline Launa- og kjarajafnrétti & $\begin{array}{l}\text { Launamunur (grunnlaun, heildarlaun). } \\
\text { Launamunur eftir starfsheiti/stöðu og eftir vinnuhlutfalli. } \\
\text { Ýmsar aðgerðir vinnuveitanda varðandi launajafnrétti. }\end{array}$ \\
\hline $\begin{array}{l}\text { Fjölskylduvænar stefnur } \\
\text { og aðgerðir }\end{array}$ & $\begin{array}{l}\text { Hlutfall starfsfólks sem er með sveigjanleika í starfi. } \\
\text { Tegund sveigjanleika. } \\
\text { Fæðingarorlof. } \\
\text { Stuðningur í boði varðandi ýmislegt tengt börnum. }\end{array}$ \\
\hline Samráð við starfsfólk & Ýmsar upplýsingar um samráð við starfsfólk hvað varðar kynjajafnrétti. \\
\hline $\begin{array}{l}\text { Annað: Kynbundin } \\
\text { áreitni og mismunun }\end{array}$ & $\begin{array}{l}\text { Er stefna og aðgerðaáætlun til staðar. } \\
\text { Meðferð mála (Verkferlar, sáttamiðlun). } \\
\text { Stjórnendapjálfun. } \\
\text { Stuðningur við starfsfólk sem verður fyrir heimilisofbeldi. }\end{array}$ \\
\hline
\end{tabular}

„Jafnréttisskorkort Ástralíu“ er að mörgu leyti sambærilegt við pann hluta gagna á vef Hagstofunnar sem lúta að pessum málum, en par eru pó umtalsvert magn upplýsingar sem tengjast ekki tilteknum mælikvörðum. Рað má segja að hlutverk WGEA sé annars vegar að safna pessum gögnum og hins vegar að sinna svipuðu hlutverki og Jafnréttisstofa gerir á Íslandi.

\subsection{Mælaborð Jafnvægisvogar FKA}

Jafnvægisvog félags kvenna í atvinnulífinu (FKA) er verkefni sem ætlað er að stuðla að breytingum. Pátttakendur í verkefninu eru fyrirtæki, opinberir aðilar og sveitarfélög. Tilgangur verkefnisins er að vinna að auknu jafnvægi milli kynja í atvinnulífinu. Mælaborð Jafnvægisvogar FKA minnir um margt á norska skorkortið sem fjallað er um í kafla 4.4. Í mælaborði Jafnvægisvogar FKA eru upplýsingar um hlutföll kynjanna og fjölda af hvoru kyni (FKA, e.d.-a). Pví er skipt upp í fjóra flokka mælikvarða og hefur hver flokkur einn til fjóra undirflokka og nokkra mælikvarða sem má sjá í töflu 6. Allir lykilmælikvarðar, nema einn, byggjst á upplýsingum frá Hagstofu Íslands, en upplýsingar um jafnlaunavottun koma frá Jafnréttisstofu (FKA, e.d.-a). 
Tafla 6. Upplýsingar í mælaborði Jafnvægisvogar FKA (FKA, e.d.-a).

\begin{tabular}{|c|c|c|}
\hline Yfirflokkur & Undirflokkur & Mælikvarðar \\
\hline \multirow[t]{2}{*}{ Hið opinbera } & Alpingi & $\begin{array}{l}\text { Kynjahlutfall kjörinna alpingismanna eftir kosningaárum og kyni. } \\
\text { Fjöldi kjörinna alpingismanna eftir kosningaárum og kyni. } \\
\text { Hlutfall kvenna á Alpingi eftir kosningaárum og aldri. }\end{array}$ \\
\hline & Sveitarstjórnir & $\begin{array}{l}\text { Kynjahlutföll kjörinna fulltrúa sveitarfélaga eftir kosningaárum. } \\
\text { Kynjahlutföll kjörinna fulltrúa eftir landssvæðum og sveitarfélögum. } \\
\text { Hlutfall kjörinna kvenna eftir landshlutum. }\end{array}$ \\
\hline Atvinnulífið & $\begin{array}{l}\text { Stjórnir og } \\
\text { framkvæmda-stjórar }\end{array}$ & $\begin{array}{l}\text { Hlutfall kvenna meðal stjórnarmanna, stjórnarformanna og } \\
\text { framkvæmdastjóra. } \\
\text { Hlutfall kvenna í stjórnum fyrirtækja eftir árum og stjórnarsetu. } \\
\text { Kynjahlutfall eftir stærð fyrirtækja. } \\
\text { Kynjahlutfall eftir atvinnugrein. } \\
\text { Kynjahlutfall stjórna og framkvæmdastjóra eftir aldri. }\end{array}$ \\
\hline \multirow[t]{2}{*}{ Menntun } & Háskólar & $\begin{array}{l}\text { Fjöldi brautskráðra eftir árum og kyni. } \\
\text { Kynjahlutföll meðal brautskráðra eftir árum. } \\
\text { Fjöldi brautskráðra eftir sviðum og kyni. } \\
\text { Fjöldi brautskráðra eftir prófgráðum og kyni. }\end{array}$ \\
\hline & Símenntun & $\begin{array}{l}\text { Pátttaka í símenntun eftir kyni. } \\
\text { Símenntun eftir aldursflokki. } \\
\text { Símenntun eftir tegund. } \\
\text { Símenntun eftir stöðu á atvinnumarkaði. }\end{array}$ \\
\hline \multirow[t]{4}{*}{ Launamál } & Launamunur & $\begin{array}{l}\text { Hvað konur péna að meðaltali sem hlutfall af tekjum karla eftir árum. } \\
\text { Samanburður við } 1000 \text { kr karla eftir atvinnugreinum. } \\
\text { Leiðréttur launamunur eftir vinnumörkuðum og árum. }\end{array}$ \\
\hline & Jafnlaunavottun & Listi yfir fyrirtæki sem hlotið hafa jafnlaunavottun. \\
\hline & Vinnustundir & $\begin{array}{l}\text { Meðalfjöldi vinnustunda í viku eftir atvinnugrein. } \\
\text { Meðalfjöldi vinnustunda á viku eftir árum. }\end{array}$ \\
\hline & Fæðingarorlof & $\begin{array}{l}\text { Hlutfallsleg kynjaskipting á fæðingarorlofi eftir árum. } \\
\text { Meðaldagafjöldi foreldris í fæðingarorlofi. } \\
\text { Meðaldagafjöldi foreldris í fæðingarorlofi eftir fæðingarári og kyni. }\end{array}$ \\
\hline
\end{tabular}

Allir mælikvarðarnir á pessu skorkorti koma til álita við gerð jafnréttisskorkorts fyrir íslenskt atvinnulíf. Peir spanna pröngt svið og eru sumir mjög sértækir pannig að ekki allir eiga heima á jafnréttisskorkorti sem á að gefa heildarmynd.

\subsection{Konur og karlar á Íslandi}

Bæklingurinn Konur og karlar á Íslandi er gefinn út árlega af Jafnréttisstofu í samstarfi við Hagstofu Íslands og forsætisráđuneytið (Hagstofa Íslands o.fl., 2019). Par eru teknar saman upplýsingar sem gefa vísbendingar um stöðu kvenna og karla í samfélaginu. Einnig eru myndrit um mannfjölda, fjölmiðla, menntun, vinnumarkað, laun og tekjur og áhrifastöður. Pessi bæklingur minnir um margt á skorkort en pó meira á mælaborð stjórnandans, sjá kafla 3. Ýmist eru gefnar upplýsingar fyrir 2019 eða sýnd próun yfir tíma. Yfirlit yfir flokka og mælikvarða bæklingsins má sjá í töflu 7. 
Tafla 7. Konur og karlar á Íslandi, flokkar og mælikvarðar (Hagstofa Íslands o.fl., 2019).

\begin{tabular}{|c|c|}
\hline Flokkur & Mælikvarðar \\
\hline Áhrifastöður & $\begin{array}{l}\text { Hlutfall kvenna af frambjóðendum og kjörnum fulltrúum í alpingiskosningum. } \\
\text { Hlutfall kvenna í forystu fyrirtækja (framkvæmdastjórar, stjórnarformenn, stjórnarmenn) } \\
\text { eftir stærð fyrirtækja. } \\
\text { Hlutfall kvenna í ýmsum áhrifastöðum í samfélaginu. }\end{array}$ \\
\hline Laun og tekjur & $\begin{array}{l}\text { Óleiðréttur launamunur kynjanna. } \\
\text { Meðalatvinnutekjur eftir menntun. }\end{array}$ \\
\hline Mannfjöldi & $\begin{array}{l}\text { Mannfjöldi eftir kyni og aldri. } \\
\text { Ýmsar upplýsingar um mannfjölda (t.d. frjósemi, fæddir, dánir, lífslíkur, öryrkjar). } \\
\text { Foreldrar í launuðu fæðingarorlofi. } \\
\text { Samsetning fjölskyldna (t.d. hjónaband, óvígð sambúð, með/án barna). }\end{array}$ \\
\hline Fjölmiðlar & Viðmælendur í fréttum og fréttatengdum páttum. \\
\hline Menntun & $\begin{array}{l}\text { Brautskráningar eftir prófgráðu. } \\
\text { Brautskráningar á háskólastigi eftir almennu sviði. } \\
\text { Mannfjöldi eftir menntunarstigi og búsetu. }\end{array}$ \\
\hline Vinnumarkaður & $\begin{array}{l}\text { Atvinnupátttaka. } \\
\text { Ýmsar upplýsingar um vinnumarkaðinn (t.d. atvinnuleysi, meðalfjöldi vinnustunda, } \\
\text { starfandi í fullu starfi/hlutastarfi). } \\
\text { Starfandi fólk eftir starfsstétt. }\end{array}$ \\
\hline
\end{tabular}

Í bæklingnum eru fjölmargar tölur sem endurspegla mun fleiri mælikvarða en væru að jafnaði á skorkorti. I mörgum tilvikum eru tölurnar ekki gefnar en pær sýndar óbeint með súluriti eða annars konar myndriti.

\subsection{Mælitæki Pórunnar Sigurðardóttur}

Í meistararitgerð Pórunnar Sigurðardóttur (2018), Ísland best í heimi? Safn mælikvarða sem sýna stöðu kynjanna í íslensku atvinnulífi, er skilgreint mælitæki sem er hliðstætt pví skorkorti sem sett er fram í pessari grein. Mælitækinu er skipt í fjórar víddir (flokka) en undir hverri vídd eru nokkrir mælikvarðar, samtals 21 mælikvarði, sjá töflu 8. Gögn fyrir flesta mælikvarðana eru frá Hagstofu Íslands en einnig eru í skorkortinu gögn frá Tryggingastofnun, Alpingi og VR (Pórunn Sigurðardóttir, 2018).

Tafla 8. Mælitæki sem sýnir stöðu kynjanna í íslensku atvinnulífi (Pórunn Sigurðardóttir, 2018).

\begin{tabular}{ll}
\hline Flokkur & Mælikvarðar \\
\hline Völd og áhrif & Hlutfall kvenna sem eiga sæti á Alpingi. \\
& Hlutfall kvenna sem eru í sveitarstjórnum. \\
& Hlutfall kvenna sem stjórnarmenn. \\
& Hlutfall kvenna sem framkvæmdastjórar. \\
& Hlutfall kvenna sem stjórnarmenn í fyrirtækjum með 50+ starfsmenn. \\
& Hlutfall kvenna sem framkvæmdastjórar í fyrirtækjum með 50+ starfsmenn. \\
\hline Atvinna og fjárhagur & Atvinnupátttaka kvenna. \\
& Atvinnubátttaka karla. \\
& Atvinnuleysi kvenna. \\
& Atvinnuleysi karla. \\
& Óleiðréttur launamunur. \\
& Kynbundinn launamunur VR. \\
\hline Fjölskylduábyrgð & Hlutfall karla og kvenna sem piggja greiðslur frá Fæðingarorlofssjóði. \\
& Skipting greiðslna frá Fæðingarorlofssjóði eftir kynjum. \\
& Hlutfall maka- og umönnunarbóta sem falla til kvenna. \\
& Hlutfall umönnunargreiðslna sem falla til kvenna. \\
& Hlutfall foreldragreiðslna sem falla til kvenna. \\
\hline Starfaskipting & Hlutfall karla og kvenna starfandi í framleiðslu. \\
& Hlutfall karla og kvenna starfandi við byggingarstarfsemi og mannvirkjagerð. \\
& Hlutfall karla og kvenna starfandi við fræðslustarfsemi. \\
& Hlutfall karla og kvenna starfandi við heilbrigðis- og félagspjónustu. \\
\hline
\end{tabular}


Segja má að niðurstöður Pórunnar séu útgangspunktur í vinnunni við pessa grein, par sem um er að ræða safn mælikvarða sem er frumútgáfa af jafnréttisskorkorti pví sem kynnt er í greininni. Sumir mælikvarðarnir eru óbreyttir eða lítt breyttir á jafnréttisskorkortinu. Aðrir eru ekki notaðir, m.a. par sem peir póttu ekki segja nógu mikið um stöðu kynjanna í atvinnulífinu, m.a. varðandi atvinnupátttöku og maka- og umönnunarbætur. Í sumum tilvikum eru valdir aðrir mælikvarðar fyrir tiltekið atriði, t.d. varðandi óleiðréttan launamun.

\subsection{Samantekt}

Í töflu 9 er samantekt á flokkum mælikvarða sem voru dregnir fram hér á undan. Flokkum er snúa að heilsu, ofbeldi og lífslíkum er sleppt. Misjafnt er hvernig flokkar eru afmarkaðir og hvaða mælikvarðar eru í flokkunum. Niðurstöður í pessari samantekt hafa áhrif á val á flokkum í jafnréttisskorkortið.

Tafla 9. Samantekt á flokkum mælikvarða.

\begin{tabular}{|c|c|c|c|c|c|c|c|}
\hline Safn & 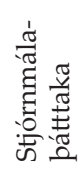 & 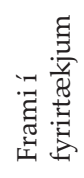 & 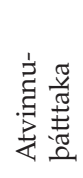 & 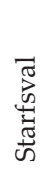 & 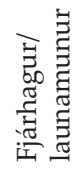 & 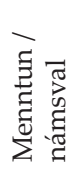 & 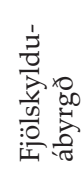 \\
\hline Heimsmarkmið SP & $\mathrm{X}$ & $x$ & $x$ & & & $x$ & $x$ \\
\hline Kynjabilið & $x$ & $x$ & $\mathrm{x}$ & $x$ & & $x$ & \\
\hline EIGE & $x$ & $x$ & $x$ & $x$ & $x$ & $x$ & $x$ \\
\hline CORE skorkortið & & $x$ & & & & & \\
\hline Jafnréttissk.k. Ástralíu & & $x$ & $x$ & $x$ & $x$ & & $x$ \\
\hline Jafnvægisvog FKA & $x$ & $x$ & & $x$ & $x$ & $x$ & \\
\hline Konur og karlar á Íslandi & $x$ & $x$ & $x$ & $x$ & $x$ & $x$ & $x$ \\
\hline Mælitæki Pórunnar & $x$ & $x$ & $x$ & $x$ & $x$ & $x$ & $x$ \\
\hline
\end{tabular}

Tvö pessara safna eru sett fram sem skorkort, CORE sem er mjög fókuserað á einn flokk, p.e. frama í fyrirtækjum og mælitæki Pórunnar sem spannar alla flokkana. Heimsmarkmið SP og vísitala kynjabils ná yfir marga pætti aðra en pá flokka sem eru í töflunni. Jafnréttisvísitölu EIGE er ætlað að vera álíka víðtæk og jafnréttisskorkortið en vísitalan nær pó yfir fleiri pætti, eins og ofbeldi og heilsu.

\section{Jafnréttisskorkort - mælikvarðar og tölur}

Í pessum kafla eru dregnir fram peir flokkar og mælikvarðar sem fram koma í jafnréttisskorkortinu. Val á mælikvörðunum er rökstutt og greint frá pví hvaðan gögn eru fengin. Á skorkortinu purfa að vera fjölbreyttir mælikvarðar sem ná yfir sem flest atriði sem eru talin skipta máli pegar kemur að stöðu kynjanna í atvinnulífinu. Eins og áður segir er tekið mið af heildarmyndinni, áhrifaritinu, sem fram kemur í mynd 1 við val á mælikvörðum. Pá er tekið mið af pví hvort gögn eru fáanleg fyrir hvern mælikvarða og hvort pau eru aðgengileg. Mælingar purfa jafnframt að vera framkvæmdar með sambærilegum hætti, á reglubundinn hátt (t.d. árlega). Раð parf einnig að vera nokkuð skýrt hvað tölurnar segja.

Jafnréttisskorkortið er safn 28 mælikvarða á stöðu kvenna og karla í atvinnulífinu. Skorkortið skiptist í fjóra flokka, sem eru; 
- Laun og atvinnupátttaka

- Völd og áhrif

- Náms- og starfsval

- Fjölskylduábyrgð

Í hverjum flokki eru fjórir til níu mælikvarðar, en fjöldi mælikvarða segir ekkert um mikilvægi flokksins. Ekki er heldur lagt mat á mikilvægi einstakra mælikvarða, en hver og einn er hluti af heildarmyndinni. Skorkortið í heild sinni má sjá á mynd 4 og í næstu undirköflum er gerð grein fyrir mælikvörðunum í hverjum flokki fyrir sig.

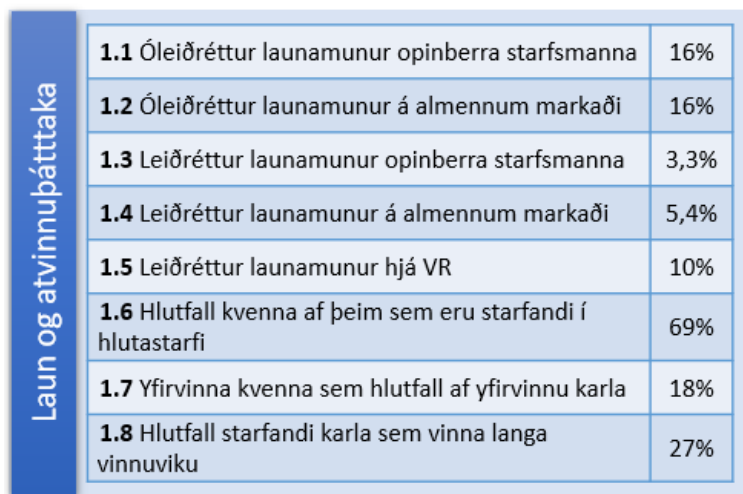

\begin{tabular}{|c|c|}
\hline $\begin{array}{l}2.1 \text { Hlutfall kvenna af stjórnarformönnum } \\
\text { fyrirtækja }\end{array}$ & $24 \%$ \\
\hline 2.2 Hlutfall kvenna í stjórnum fyrirtækja & $26 \%$ \\
\hline $\begin{array}{l}\text { 2.3 Hlutfall kvenna í stjórnum fyrirtækja með } 50+ \\
\text { starfsmenn }\end{array}$ & $34 \%$ \\
\hline $\begin{array}{l}\text { 2.4 Hlutfall kvenna af framkvæmdastjórum } \\
\text { fyrirtækja }\end{array}$ & $23 \%$ \\
\hline $\begin{array}{l}\text { 2.5 Hlutfall kvenna af framkvæmdastjórum } \\
\text { fyrirtækja með } 50+\text { starfsmenn }\end{array}$ & $13 \%$ \\
\hline 2.6 Hlutfall kvenna sem eiga sæti á Alpingi & $38 \%$ \\
\hline 2.7 Hlutfall kvenna í sveitarstjórnum & $47 \%$ \\
\hline 4.1 Meðallengd fæðingarorlofs karla (\% af konum) & $43 \%$ \\
\hline 4.2 Meðallengd fæðingarorlofs karla (dagafjöldi) & $\begin{array}{c}78 \\
\text { dagar }\end{array}$ \\
\hline 4.3 Hlutfall umönnunargreiðsIna til kvenna & $87 \%$ \\
\hline $\begin{array}{l}\text { 4.4 Tími karla í heimilisstörf sem hlutfall af tíma } \\
\text { kvenna }\end{array}$ & $67 \%$ \\
\hline
\end{tabular}

Mynd 4. Jafnréttisskorkort fyrir íslenskt atvinnulíf. Flestar tölurnar eru frá 2018, en frá 2017 fyrir mælikvarða 1.1, 1.2, 4.1 og 4.2, frá 2016 fyrir mælikvarða 1.3 og 1.4 og frá 2013 fyrir mælikvarða 4.4 .

\subsection{Laun og atvinnupátttaka}

Í pessum flokki eru átta mælikvarðar sem veita upplýsingar um launamun kynjanna og mun á atvinnupátttöku karla og kvenna. Mælikvarðar 1.1-1.5 snúast um launamun kynjanna og mælikvarðar 1.6-1.8 um atvinnupátttöku og vinnutíma.

\subsubsection{Launamunur}

Launamunur kynjanna hefur verið eitt af áhersluatriðum jafnréttisbaráttunnar undanfarna áratugi og er pað ennpá. Á áhrifaritinu á mynd 1 er sver rammi um petta atriði vegna pess að pátttakendur í rýnihópunum töldu mögulegt að draga fram mælikvarða fyrir launamun kynjanna og reyndar má mæla hann á ýmsa vegu og hver mælikvarði segir sína sögu. Prjú atriði hafa mikil áhrif á hvað mælikvarðinn segir, en pau eru hvaða hópar eru lagðir til grundvallar, hvaða laun eru skoðuð og hvort notaðar séu skýribreytur.

Hver mælikvarði fyrir launamun kynjanna setur fram mun á launum kvenna og karla fyrir tiltekinn hóp launafólks. Petta geta t.d. verið allir félagsmenn VR eða allir opinberir 
starfsmenn. Oft er aðeins hluti hópsins lagður til grundvallar, t.d. aðeins peir sem vinna fulla vinnu. Algengt er að nota föst laun, dagvinnulaun, heildarlaun eða tímakaup, en aðrar útfærslur eru líka pekktar. Ekkert af pessu gefur „rétta mynd“, en hver mælikvarði segir sína sögu.

Pegar reiknaður er „,kynbundinn launamunur“, ,"leiðréttur launamunur“ eða „,skýrður launamunur" pá er byrjað á að taka tillit til atriða annarra en kyns, sem talið er eðlilegt að hafi áhrif á laun. Рað atriði sem yfirleitt er byrjað á að taka tillit til er vinnutími, enda telst eðlilegt að peir sem vinna lengri vinnudag fái að jafnaði hærri laun en peir sem vinna styttri vinnudag. Önnur atriði sem stundum er tekið tillit til eru starf, menntun, ábyrgð, aldur og reynsla (Hagtíðindi, 2018). •að má deila um pað hvaða breytur eigi að hafa með og hvað má telja til eðlilegra skýringa eins og bent hefur verið á (Forsætisráðuneytið, 2020; Porgerður Einarsdóttir og Kristjana Stella Blöndal, 2004). Ef slík atriði eru ekki tiltekin pá er talað um „óleiðréttan launamun“.

Í skorkortinu eru fimm mælikvarðar fyrir launamun kynjanna sem til samans gefa gleggri mynd en einn eða tveir mælikvarðar. Fyrstu fjórir mælikvarðarnir byggja á tölum frá Hagstofu Íslands (Hagstofa Íslands, e.d.-a, e.d.-b), en sá fimmti á tölum frá VR („Launamunur kynjanna“, e.d.). Fyrstu tveir sýna óleiðréttan launamun, annars vegar hjá opinberum starfsmönnum og hins vegar á almennum markaði. Næstu tveir sýna leiðréttan launamun fyrir sömu hópa. Hagstofan byggir útreikning sinn á óleiðréttum launamun kynjanna á aðferðafræði sem Hagstofa Evrópusambandsins (Eurostat) notar í rannsókn sinni á uppbyggingu launa (e. structure of earnings survey), sem framkvæmd er á fjögurra ára fresti. Við útreikninginn eru mánaðarlaun (fastar reglulegar greiðslur auk yfirvinnu) í október höfð til grundvallar (óreglulegar greiðslur sem falla til í október eru undanskildar). Pessi aðferð er talin sambærileg við pað sem Hagstofan kallar regluleg heildarlaun í öðru talnaefni. Við útreikning á leiðréttum launamun er notast við svokallaða Oaxaca aðferð (Sigurður Snævarr, 2015). Oaxaca aðferðin er kennd við hagfræðinginn Ronald Oaxaca (1973) og er algeng pegar mæla á mismun milli hópa. Aðferðin byggir á reiknilíkani par sem skilgreindar eru hinar ýmsu stýribreytur sem eru taldar hafa áhrif á launamun. Útkoman er svo sundurliðun í skýrðan og óútskýrðan launamun, p.e.a.s. hversu mikið af launamuninum er hægt að skýra með peim breytum sem eru settar inn í reiknilíkanið og hversu mikill munur stendur eftir óútskýrður (Hagtíðindi, 2018; Porgerður Einarsdóttir og Kristjana Stella Blöndal, 2004).

Síðasti mælikvarðinn um launamun kynjanna er um félagsmenn í VR („Launamunur kynjanna“, e.d.) en pessi launamunur hefur verið mældur reglulega af stéttarfélaginu frá árinu 2003. Mælikvarðinn gefur pann mun sem er á launum karla og kvenna pegar búið er að taka tillit til helstu áhrifapátta á laun, sem eru vinnutími, aldur, starfsaldur, starfsog atvinnugreinar, menntun, mannaforráð og vaktavinna. Einungis eru borin saman laun einstaklinga í fullu starfi.

Mælikvarðarnir fimm um launamun eru eftirfarandi:

- Mælikvarði 1.1: Óleiðréttur launamunur opinberra starfsmanna.

- Mælikvarði 1.2: Óleiðréttur launamunur á almennum vinnumarkaði.

- Mælikvarði 1.3: Leiðréttur launamunur opinberra starfsmanna.

- Mælikvarði 1.4: Leiðréttur launamunur á almennum vinnumarkaði.

- Mælikvarði 1.5: Leiðréttur launamunur hjá VR.

Mynd 5 sýnir að launamunur kynjanna er mjög misjafn eftir hópum og hvaða mælikvarði er notaður. Pannig sést greinilega að óleiðréttur launamunur er mun meiri en leiðréttur launamunur og ein af meginskýringum pess er að launaður vinnutími karla er lengri en kvenna. Einnig er launamunur minni hjá opinberum starfsmönnum en á almennum vinnumarkaði. Hjá félagsmönnum VR mælist launamunur meiri en á almennum vinnumarkaði 
og að öllum líkindum er meginástæðan sú að launamunurinn er leiðréttur á annan hátt hjá VR en hjá Hagstofunni.

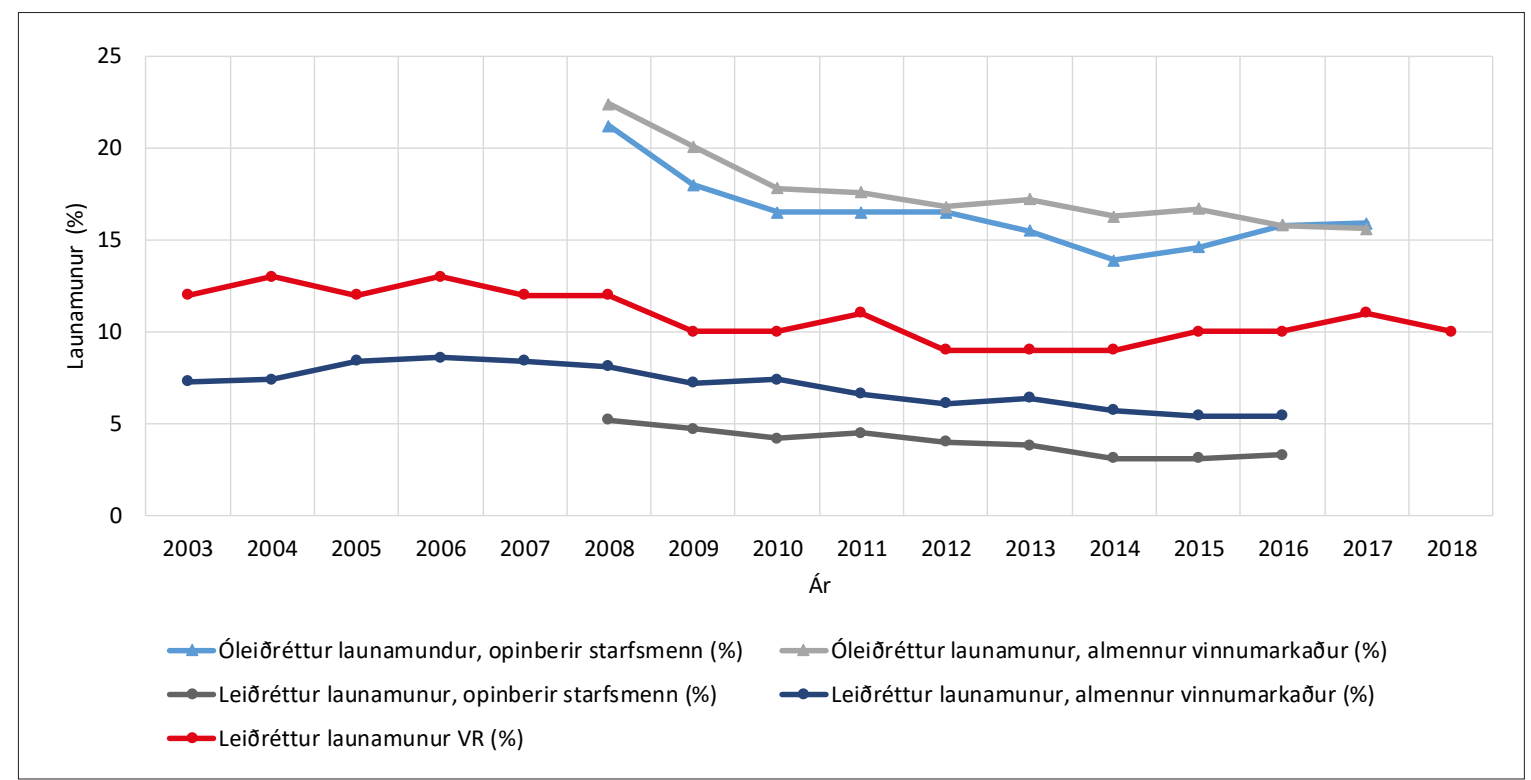

Mynd 5. Mælikvarðar um launamun kynjanna (Hagstofa Íslands, e.d.-a, e.d.-b; „Launamunur kynjanna“, e.d.).

\subsubsection{Atvinnupátttaka og vinnutími}

Eins og kom fram í kafla 2 sýna fjölmargar rannsóknir að karlar verja að jafnaði meiri tíma í launaða vinnu, en á móti verja konur meiri tíma í að sinna ólaunuðum heimilis- og umönnunarstörfum. Pannig veita mælikvarðar um atvinnupátttöku ekki aðeins upplýsingar um vinnutíma heldur gefa einnig vísbendingu um tíma sem er varið í ólaunuð heimilisog umönnunarstörf. Hér eru notaðir prír mismunandi mælikvarðar sem allir gefa upplýsingar um mismunandi vinnutíma kynjanna, en hver á sinn hátt.

Fyrstu tveir mælikvarðarnir (1.6 og 1.7) koma úr vinnumarkaðsrannsókn Hagstofu Íslands (Hagstofa Íslands, e.d.-c, e.d.-d). Starfandi telst allt fólk (á aldrinum 16-74 ára) sem vinnur einhverjar stundir í tiltekinni viðmiðunarviku.

Mælikvarði 1.6 sýnir í hve miklum mæli konur, frekar en karlar, vinna hlutastörf. Einstaklingur telst vera í hlutastarfi ef hann vinnur 1-34 klst. að jafnaði á viku. Pegar kemur að ástæðu hlutastarfa á Íslandi pá nefnir priðjungur kvenna fjölskylduástæður en enginn karlanna (Lanninger og Sundström, 2014).

Mælikvarði 1.7 sýnir í hve miklum mæli karlar vinna fleiri yfirvinnustundir en konur. Notast er við tölur um vinnustundir fólks í fullu starfi og var ákveðið að tímar umfram 40 klst. vinnuvinnu (sbr. lög um 40 stunda vinnuviku nr. 88/1971) teldust vera yfirvinna, pó að vissulega séu mismunandi forsendur á bakvið pað hvað telst full vinnuvika. Mælikvarðinn segir hve margar yfirvinnustundir konur vinna að meðaltali miðað við karla, pannig að talan er 100\% ef kynin vinna að meðaltali jafn margar yfirvinnustundir.

Mælikvarði 1.8 sýnir hlutfall starfandi karla (á aldrinum 20-64 ára) sem vinna langa vinnuviku (49+ klst.). Að vinna langa vinnuviku að jafnaði prengir mjög að peim tíma sem fólk hefur til umráða til að sinna öðrum páttum lífs síns, eins og t.d. fjölskyldu, vinum, líkamsrækt og áhugamálum. Miklu meira er um раð аð karlar vinni langan vinnudag og er pað ein af skýringunum á pví að karlar taka minni pátt í heimilisstörfum en konur. Tölurnar fyrir pennan mælikvarða eru hluti af evrópsku vinnumarkaðsrannsókninni, sem er framkvæmd árlega af Hagstofu Evrópusambandsins (Eurostat, e.d.).

Mælikvarðarnir prír eru eftirfarandi: 
- Mælikvarði 1.6: Hlutfall kvenna af peim sem eru starfandi í hlutastarfi.

- Mælikvarði 1.7: Yfirvinna kvenna sem \% af yfirvinnu karla.

- Mælikvarði 1.8: Hlutfall starfandi karla sem vinna langa vinnuviku að jafnaði.

Mynd 6 sýnir próun talna um atvinnupátttöku og vinnutíma og par sést að mun fleiri konur en karlar eru í hlutastarfi og hefur hlutfallið aðeins lækkað lítillega á tímabilinu 2003 til 2018, var tæplega 80\% í upphafi tímabilsins en er um 70\% í lok pess, pannig að ójöfnuðurinn hefur minnkað lítið en greinilega. Svipaða próun má sjá varðandi yfirvinnustundir, en í upphafi tímabilsins var meðalfjöldi yfirvinnustunda kvenna tæplega $30 \%$ af yfirvinnustundum karla en tæplega $20 \%$ í lok pess, pannig að ójöfnuðurinn varðandi petta atriði hefur aukist lítilsháttar. Hlutfall karla sem vinna að jafnaði langa vinnuviku lækkaði umtalsvert frá 2000 til 2009, en hefur lítið breyst síðan pá. Prátt fyrir að hlutfall peirra sem vinna að jafnaði langa vinnuviku hafi lækkað var Ísland með annað hæsta hlutfallið í Evrópu árið 2018.

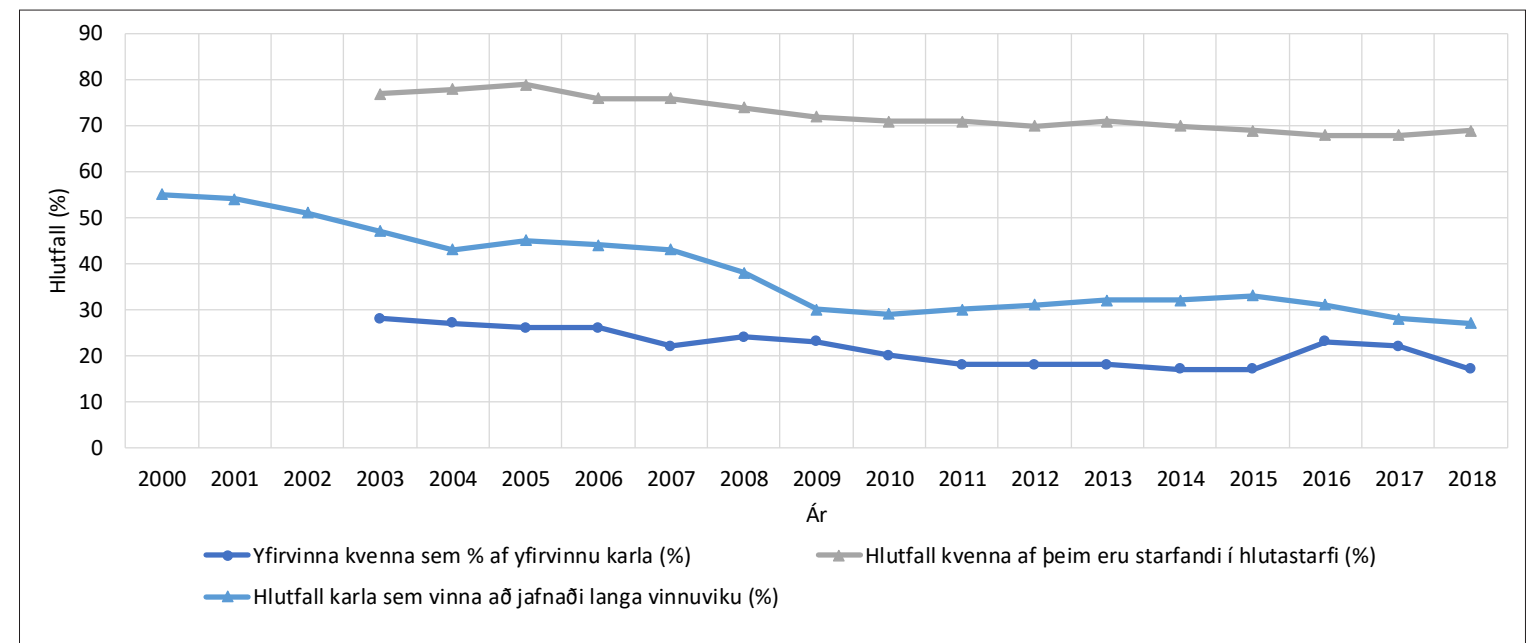

Mynd 6. Mælikvarðar um atvinnupátttöku og vinnutíma (Eurostat, e.d.; Hagstofa Íslands, e.d.-c, e.d.-d).

\subsection{Völd og áhrif}

Mælikvörðum í flokknum völd og áhrif má skipta í tvennt. Fyrstu fimm mælikvarðarnir (2.1-2.5) ná yfir völd og ábyrgð innan fyrirtækja á Íslandi og tengjast peir atriðinu „Jafnari hlutföll í framkvæmdastjórnum“ á áhrifaritinu. Hinir mælikvarðarnir ná svo yfir pólitísk völd (2.6-2.7), en peir tengjast nokkrum atriðum á áhrifaritinu, m.a. „Staðalmyndir fjari út“. Við fjöllum fyrst um fimm fyrstu og síðan um hina tvo.

\subsection{1 Æðstu stjórnendur í fyrirtækjum}

Á skorkortinu eru fimm mælikvarðar um stöðu kvenna í efstu lögum fyrirtækja á Íslandi, prír um stjórnarsetu og tveir um kynjahlutföll meðal framkvæmdastjóra. Stjórnarformenn hafa mun meiri völd og áhrif en almennir stjórnarmenn og pví er sérstakur mælikvarði fyrir formenn. Sérstakir mælikvarðar sýna hlutfall kvenna sem eru framkvæmdastjórar og stjórnarmenn hjá fyrirtækjum með 50 eða fleiri starfsmenn, en lög kveða á um hlutföll kynja í stjórnum slíkra fyrirtækja, sjá umföllun um mynd 7.

Tölur fyrir alla mælikvarðana eru fengnar af vef Hagstofunnar (Hagstofa Íslands, e.d.-e, e.d.-f). Hagstofan fær upplýsingar um skráđa framkvæmdastjóra, stjórnarformenn og stjórnarmenn úr hlutafélagaskrá og í birtum gögnum Hagstofunnar eru eingöngu virk félög.

Mælikvarðarnir fimm eru eftirfarandi: 
- Mælikvarði 2.1: Hlutfall kvenna af stjórnarformönnum fyrirtækja.

- Mælikvarði 2.2: Hlutfall kvenna í stjórnum fyrirtækja.

- Mælikvarði 2.3: Hlutfall kvenna í stjórnum fyrirtækja með 50 eða fleiri starfsmenn.

- Mælikvarði 2.4: Hlutfall kvenna af framkvæmdastjórum hjá fyrirtækjum.

- Mælikvarði 2.5: Hlutfall kvenna af framkvæmdastjórum fyrirtækja með 50 eða fleiri starfsmenn.

Mynd 7 sýnir tölulega próun stöðu kvenna í æðstu stjórn fyrirtækja og pegar horft er á öll fyrirtæki pá eykst hlutfall kvenna í stjórnum og sem framkvæmdastjórar stöðugt en hægt yfir tímabilið 1999-2018. Árið 2018 eru mælikvarðar 2.1, 2.2 og 2.4 eru með gildin $24 \% 26 \%$ og 23\% pannig að enn er langt í land að hlutfallið nái 50\%. Mælikvarðarnir fyrir fyrirtæki með 50 eða fleiri starfsmenn sýna ólíka próun. Án vafa höfðu breytingar sem gerðar voru árið 2010 (nr. 13/2010) á lögum um einkahlutafélög (nr. 138/1994) og lögum um hlutafélög (nr. 2/1995) mikil áhrif. Breytingarnar miðuðu að pví að jafna hlut kynjanna í stjórnum fyrirtækja og kveða lögin nú á um að í félagi par sem starfsmenn eru 50 eða fleiri pá skuli hlutfall hvors kyns í stjórn ekki vera lægra en 40\%. Hlutfall kvenna í stjórnum fyrirtækja með 50 eða fleiri starfsmenn hefur aukist mjög mikið á tímabilinu 1999-2018, eða úr 9\% í $34 \%$. Hlutfall kvenna meðal framkvæmdastjóra fyrirtækja með 50 eða fleiri starfsmen var undir 5\% um aldamótin og hefur einungis aukist upp í 13\% árið 2018.

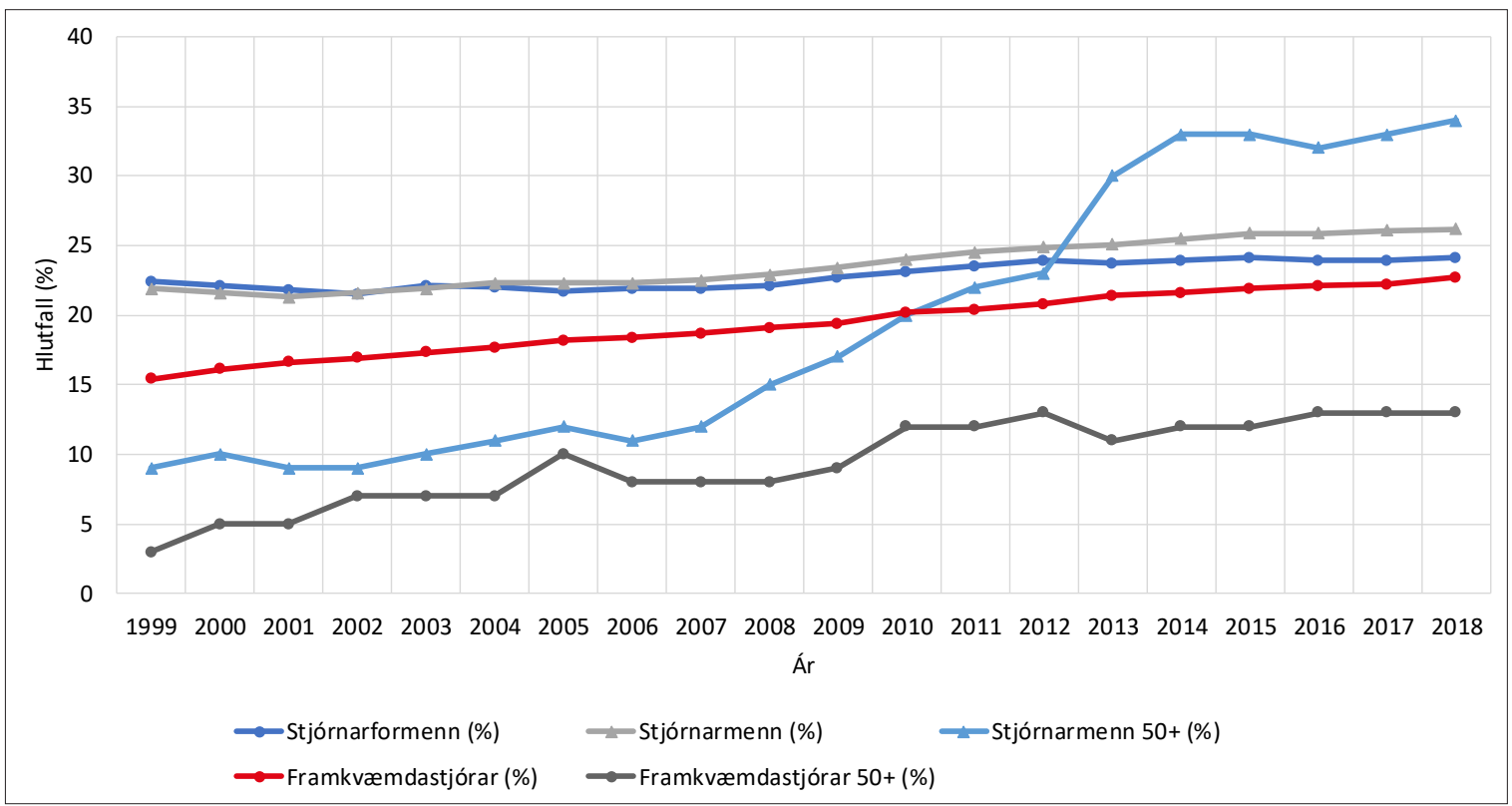

Mynd 7. Mælikvarðar um hlut kvenna í forystu fyrirtækja. (Hagstofa Íslands, e.d.-e, e.d.-f).

\subsubsection{Pólitísk völd}

Undir pólitísk völd falla tveir mælikvarðar, hlutfall kvenna á Alpingi og í sveitarstjórnum. Hagstofan birtir töluleg gögn um hlutfall kvenna á Alpingi og í sveitarstjórnum eftir kosningaárum (Hagstofa Íslands, e.d.-g, e.d.-h).

Mælikvarðarnir eru eftirfarandi:

- Mælikvarði 2.6: Hlutfall kvenna sem eiga sæti á Alpingi.

- Mælikvarði 2.7: Hlutfall kvenna í sveitarstjórnum.

Eðli málsins samkvæmt pá sveiflast hlutfall milli kosninga og kosningar eru yfirleitt haldnar á fjögurra ára fresti. Ef litið er á próun talna um pólitísk völd á mynd 8 má segja 
að lítið vanti upp á að jöfnuði milli kynjanna í sveitarstjórnum sé náð. Bakslag varð í alpingiskosningum 2017, en líklegt má telja að pað sé tímabundið bakslag.

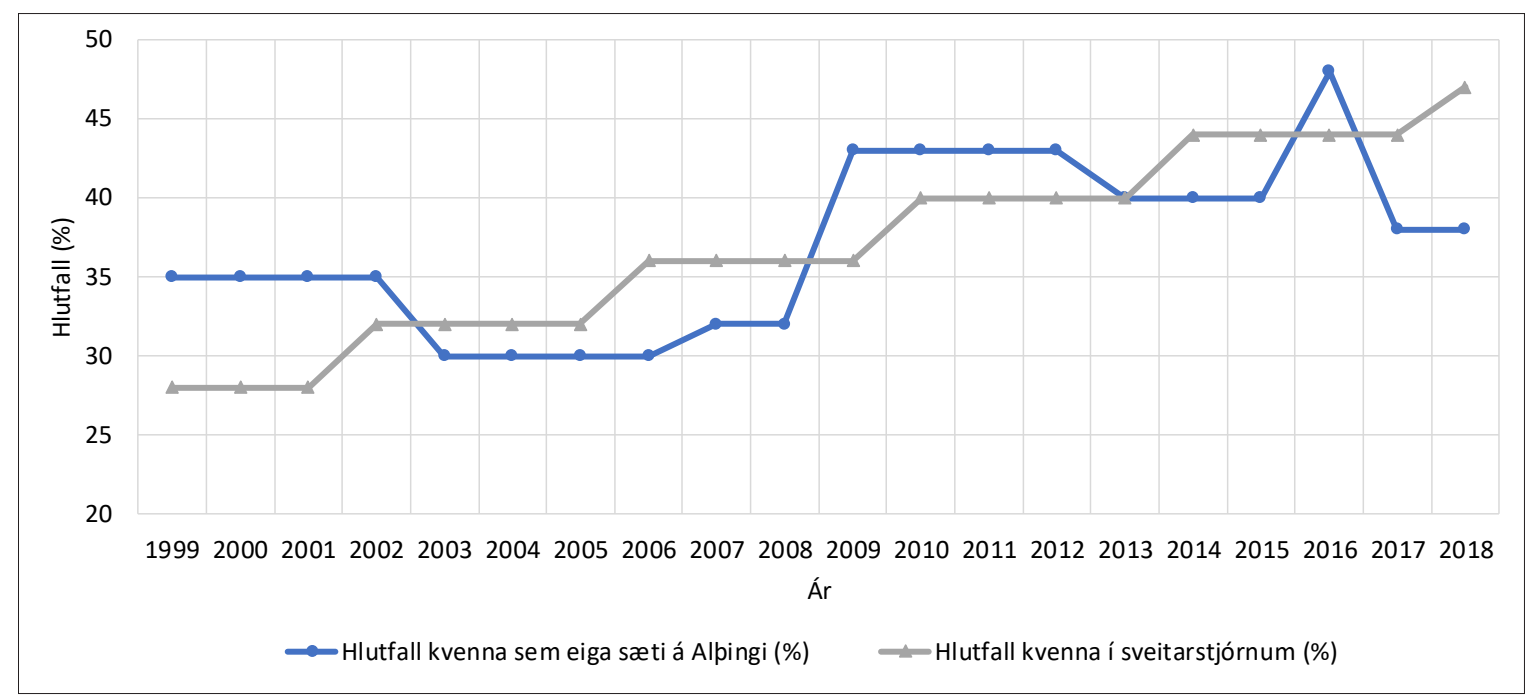

Mynd 8. Mælikvarðar um pólitísk völd (Hagstofa Íslands, e.d.-g, e.d.-h).

\subsection{Náms- og starfsval}

Einn angi af kynjamuni í íslensku atvinnulífi eru svokölluð kvenna- og karlastörf. Til að tiltekin starfsstétt teljist „karlastétt" eða „kvennastétt“ er miðað við að hlutfall annars kynsins sé 2/3 hlutar eða meira (Katrín Ólafsdóttir og Steinunn Rögnvaldsdóttir, 2015). Hér er horft á lárétta skiptingu vinnumarkaðarins (p.e.a.s. að konur og karlar gegna ólíkum störfum), en tölur um lóðrétta skiptingu vinnumarkaðarins (p.e.a.s. að konur og karlar hljóta ólíkan framgang í starfi) hafa verið ræddar hér áður undir flokknum völd og áhrif.

Tiltekið nám er oft forsenda fyrir tiltekið starf eins og dregið er fram á áhrifaritinu. Pess vegna er ein af forsendum pess að breyta kynjahlutföllum í mörgum kvenna- og karlastéttum sú að námsval verði minna kynbundið, sjá áhrifarit. Við fjöllum um mælikvarðana í pessum flokki í tvennu lagi, fyrst um námsval (mælikvarðar 3.1-3.4) og síðan um starfaskiptingu (mælikvarðar 3.5-3.9).

\subsubsection{Námsval}

Valdir voru fjórir mælikvarðar sem taldir eru gefa skýra mynd af kynbundnu námsvali. Fyrstu prír mælikvarðarnir (3.1-3.3) ná yfir brautskráningar á háskólastigi af ákveðnum sviðum og fjórði mælikvarðinn (3.4) nær yfir kynjaskiptingu í iðnnámi.

Mælikvarðarnir eru eftirfarandi:

- Mælikvarði 3.1: Hlutfall kvenna sem brautskrást af heilbrigðis- og velferðarsviði.

- Mælikvarði 3.2: Hlutfall kvenna sem brautskrást með gráðu í raunvísindum, stærðfræði og tölvunarfræði.

- Mælikvarði 3.3: Hlutfall kvenna sem brautskrást með gráðu í verkfræði, framleiðslu og mannvirkjagerð.

- Mælikvarði 3.4: Hlutfall kvenna meðal peirra sem brautskrást með sveinspróf.

Tölur fyrir mælikvarðana eru fengnar frá Hagstofu Íslands (Hagstofa Íslands, e.d.-i, e.d.-j), en Hagstofan safnar gögnum frá skólum á háskólastigi sem brautskrá nemendur í lok hvers misseris. Flokkunin er samkvæmt íslensku náms- og menntunarflokkuninni (ÍSNÁM2008) sem er byggð á alpjóðlegu menntaflokkuninni (ISCED97). Hagstofan fær upplýsingar um sveinspróf frá mennta- og menningarmálaráðuneytinu en ráðherra mennta- 
mála ber ábyrgð á að haldin séu sveinspróf fyrir iðnnema í löggiltum iðngreinum og heldur skrá yfir alla sem lokið hafa sveinsprófi (nr. 698/2009).

pegar mynd 9 um próun námsvals er skoðuð sést að litlar breytingar hafa átt sér stað á tímabilinu. Svolitlar breytingar eru milli ára en pær virðast einkum vera tilviljunarkenndar eða tímabundnar frekar en að um langtímapróun sé að ræða. Við túlkun á pessum mælikvarða er ágætt að hafa í huga að heildarskipting brautskráðra úr háskóla árið 2017-2018 var með peim hætti að konur voru um 65\% og karlar 35\% (Hagstofa Íslands, 2020).

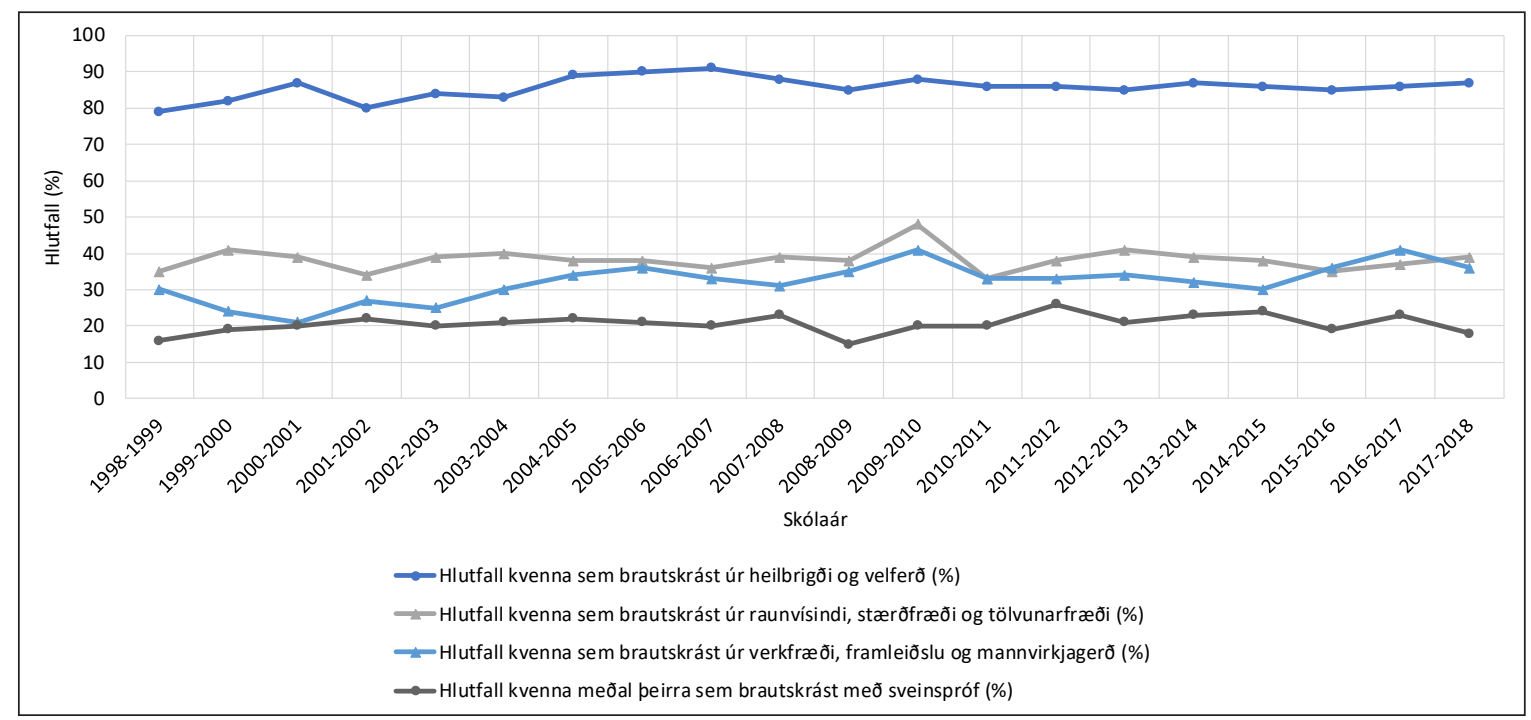

Mynd 9. Mælikvarðar um kynbundið námsval. (Hagstofa Íslands, e.d.-i, e.d.-j).

\subsubsection{Kynjahlutföll í störfum}

Fyrstu fjórir mælikvarðarnir (3.5-3.8) snúa að tilteknum atvinnugreinum sem eru töluvert kynjaskiptar, tvær par sem meirihlutinn eru karlar (3.5 og 3.6) og tvær par sem konur eru í meirihluta (3.7 og 3.8). Síðasti mælikvarðinn (3.9) sýnir hlutfall kvenna meðal iðnaðarmanna, sem er karllæg starfsstétt.

Mælikvarðarnir eru eftirfarandi:

- Mælikvarði 3.5: Hlutfall kvenna í framleiðslu.

- Mælikvarði 3.6: Hlutfall kvenna í byggingastarfsemi og mannvirkjagerð.

- Mælikvarði 3.7: Hlutfall kvenna í fræðslustarfsemi.

- Mælikvarði 3.8: Hlutfall kvenna í heilbrigðis- og félagspjónustu.

- Mælikvarði 3.9: Hlutfall kvenna meðal iðnaðarmanna.

Tölur fyrir mælikvarðana eru fengnar frá Hagstofu Íslands (Hagstofa Íslands, e.d.-k, e.d.-1), p.e. úr Vinnumarkaðsrannsókn Hagstofunnar, en hún er hluti af samstarfi EESríkja. Um langtímarannsókn er að ræða, par sem úrtak sem telur um 4.000 einstaklinga er valið úr Pjóðskrá. Flokkun í atvinnugreinar er í samræmi við íslensku atvinnugreinaflokkunina (ÍSAT2008) sem er byggð á atvinnugreinaflokkun Evrópusambandsins (NACE REV.2). Flokkun Hagstofunnar í starfsstéttir er í samræmi við íslensku starfaflokkunina (ÍSTARF95) sem er byggð á alpjóðastarfaflokkuninni (ISCO88).

Pegar mynd 10 er skoðuð sést að litlar breytingar á starfsvali hafa átt sér stað á tímabilinu. Svolitlar breytingar eru milli ára en pær virðast einkum vera tilviljunarkenndar eða tímabundnar breytingar frekar en að um langtímapróun sé að ræða. 


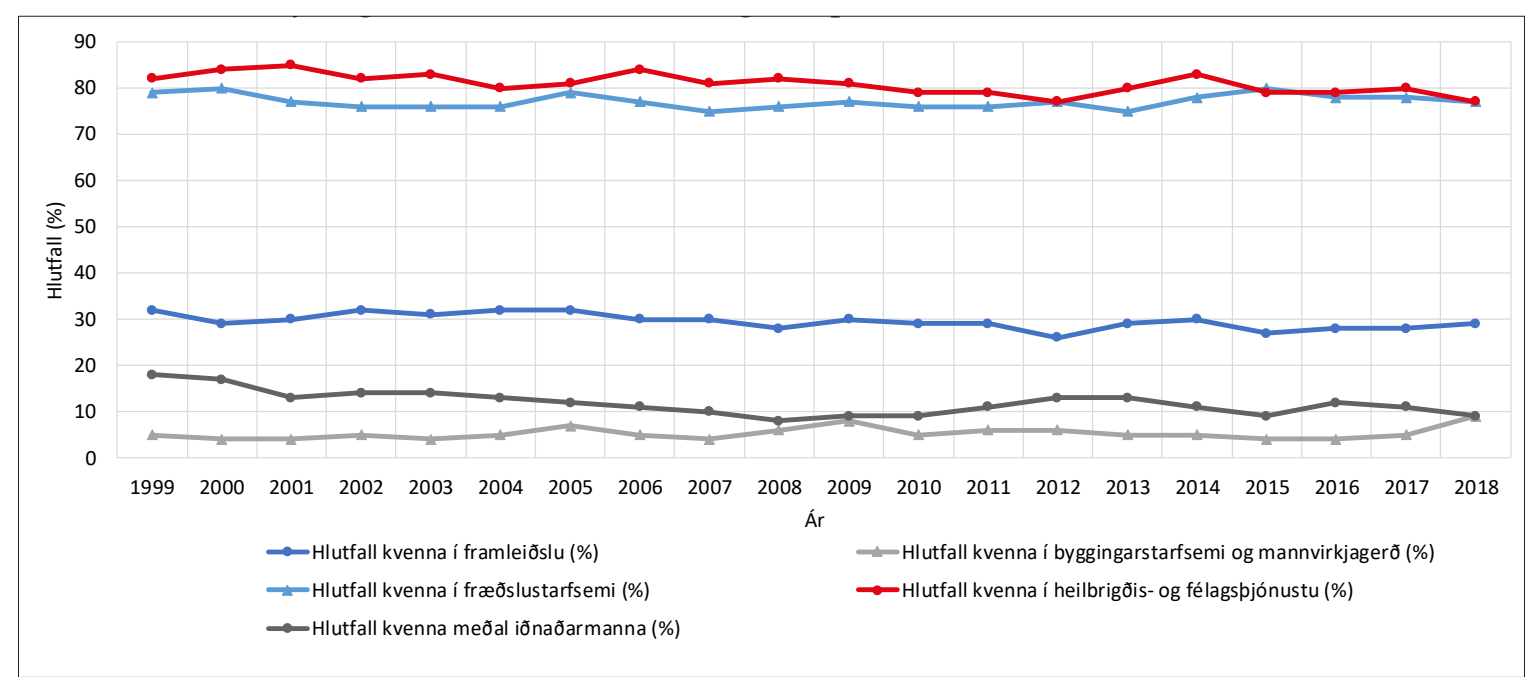

Mynd 10. Mælikvarðar um kynbundið starfsval. (Hagstofa Íslands, e.d.-k, e.d.-l).

\subsection{Fjölskylduábyrgð}

Ljóst er að ein af meginástæðum pess að konur verja færri klukkustundum í launuð störf en karlar og ná minni frama í fyrirtækjum er að pær bera meiri ábyrgð á ólaunuðum heimilis- og umönnunarstörfum. Forsenda pess að jafna stöðu kynjanna í atvinnulífinu er pví að jafna fjölskylduábyrgð, en mörg atriði á áhrifaritinu snúast um pað. Umönnun og uppeldi barna vegur pungt í fjölskylduábyrgð en ýmislegt annað skiptir líka máli, t.d. umönnun veikra maka, foreldra eða annarra skyldmenna og almenn heimilisstörf, eins og prif, pvottur og eldamennska.

Fjölskylduábyrgð er flókið fyrirbæri og erfitt að skilgreina mælikvarða sem veita miklar upplýsingar um hana. Auk pess er upplýsingum um skiptingu fjölskylduábyrgðar ekki safnað mjög reglulega á Íslandi frekar en annars staðar. Á skorkortinu eru fjórir mælikvarðar sem hver um sig varpar einhverju ljósi á stöðuna og til samans gefa peir gleggri mynd af henni en ella. Fyrst koma tveir mælikvarðar um fæðingarorlof (4.1 og 4.2) og svo eru tveir mælikvarðar um heimilisstörf og umönnun (4.3 og 4.4).

Mælikvarðarnir tveir sem tengjast fæðingarorlofi segja ólíka hluti og segja pví meira til samans en hvor fyrir sig. Sá fyrri mælir hvernig kynin skipta með sér fæðingarorlofi og mælir pví kynjamun beint. Sá seinni tiltekur fjölda daga sem feður taka í fæðingarorlofi, en ætla má að ef fjöldi daga eykst pá læri feður betur að taka ábyrgð á umönnun barna og fjölskylduábyrgð almennt.

Fæðingarorlofskerfið er með peim hætti að hvort foreldri á sjálfstæðan rétt til fæðingarorlofs og að auki er sameiginlegur réttur sem foreldrar geta skipt milli sín eins og peir kjósa. Lengd fæðingarorlofs og sjálfstæði rétturinn hefur sveiflast yfir tímabilið. Árið 2001 var sjálfstæður réttur feðra einn mánuður, árið 2002 var rétturinn tveir mánuðir og svo prír mánuðir frá og með árinu 2003.

Töluleg gögn fyrir mælikvarðana eru fengin frá Hagstofu Íslands, en Hagstofan safnar pessum gögnum frá Vinnumálastofnun og Fæðingarorlofssjóði sem halda utan um pessar greiðslur (Hagstofa Íslands, e.d.-m). Par sem foreldrar geta tekið fæðingarorlof fyrstu tvö árin frá fæðingu barns pá eru tölulegar upplýsingar fyrir börn fædd 2016 fyrst komnar að fullu fram í lok árs 2018.

Umönnunargreiðslur eru greiddar til foreldra barna sem glíma við fötlun eða veikindi, skv. 4. gr. laga um félagslega aðstoð (nr. 99/2007). Gögn um umönnunargreiðslur eru úr bókhaldi Tryggingastofnunar Íslands og eru aðgengilegar á vef stofnunarinnar (Tryggingastofnun, e.d.).

Ákveðin áskorun var fólgin í pví að finna mælingar á pví hvernig skipting heimilis- 
og umönnunarstarfa er háttað. Að lokum var ákveðið að draga fram gögn úr alpjóðlegu félagsvísindarannsókninni (ISSP) sem Félagsvísindastofnun hefur séð um framkvæmd á hérlendis síðan árið 2009. Kannanirnar hafa ólík pemu eftir árum, en spurt er út í ólaunuð heimilis- og umönnunarstörf á tíu ára fresti undir pemanu fjölskyldan og breytt kynjahlutverk (e. family and changing gender roles). Síðasta könnun með pessu pema var gerð árið 2012 (2013 á Îslandi) svo næst verður petta pema til rannsóknar árið 2022 (ISSP, e.d.).

Mælikvarðarnir eru eftirfarandi:

- Mælikvarði 4.1: Meðallengd fæðingarorlofs karla sem hlutfall af meðallengd fæðingarorlofs kvenna.

- Mælikvarði 4.2: Meðallengd fæðingarorlofs karla (dagafjöldi).

- Mælikvarði 4.3: Hlutfall umönnungargreiðslna sem falla til kvenna.

- Mælikvarði 4.4: Tími sem karlar verja í heimilisstörf sem hlutfall (\%) af tímanum sem konur verja í heimilisstörf.

Mynd 11 sýnir próun fjölskylduábyrgðar og nýtingu feðra á fæðingarorlofi. Báðir mælikvarðar fæðingarorlofs sýna mikla aukningu í pátttöku feðra frá 2001 til 2003 og er pað bein afleiðing af breyttu fæðingarorlofskerfi. Pátttaka feðra dregst lítillega saman frá árinu 2008, mest fyrstu 4 árin og svo aftur milli 2016 og 2017. Ein af ástæðunum er eflaust breytingar á fæðingarorlofskerfinu, en hámarksgreiðslur voru lækkaðar árið 2009 og hlutfall af launum lækkað árið 2010. Frá og með árinu 2020 er sjálfstæður réttur hvors foreldris fjórir mánuðir og má ætla að áhrif pess byrji að koma fram árið 2021 og svo af fullum punga 2022.

Varðandi bótagreiðslur pá sýnir mynd 11 að staðan hefur nánast ekkert breyst, konur fá 86-88\% af umönnunargreiðslum til foreldra barna sem glíma við fötlun eða veikindi, en slíkt er pá vísbending um að konur sinni umönnuninni mun meira en karlar.

Síðasti mælikvarðinn á mynd 11 sýnir að hlutur karla í heimilisstörfum hefur aukist nokkuð frá 2005 til 2013, en hafa parf í huga að fáar og stopular mælingar eru fyrir pennan mælikvarða.

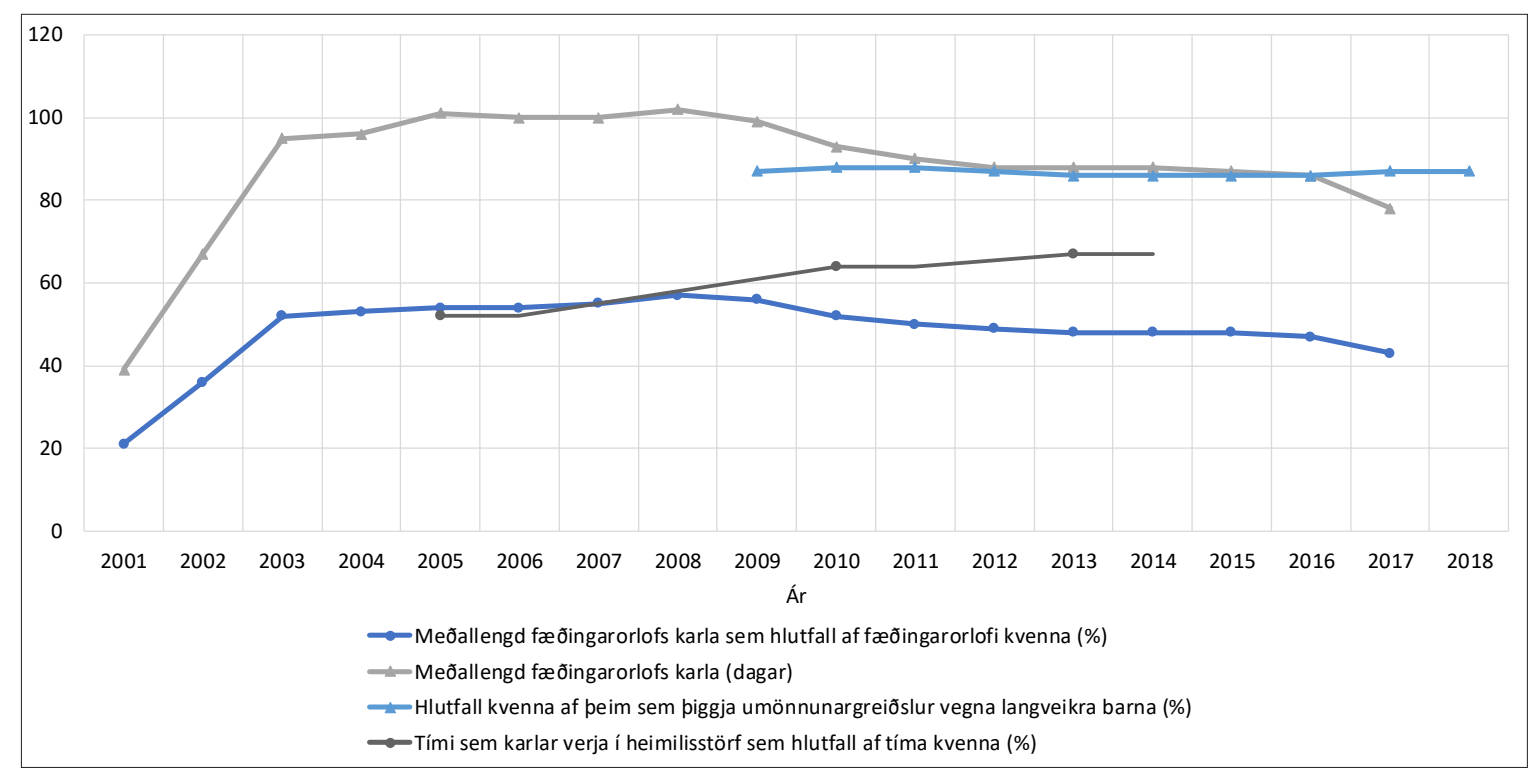

Mynd 11. Mælikvarðar um fjölskylduábyrgð (Hagstofa Íslands, e.d.-m; ISSP, e.d.; Tryggingastofnun, e.d.). 


\section{Umræour og lokaorð}

Í pessari rannsókn var lagt upp með tvær rannsóknarspurningar: Hvaða safn mælikvarða, sett fram í jafnréttisskorkorti, gefur heildarmynd af stöðu kynjanna i íslensku atvinnulífi? og Hver er staða kynjanna i íslensku atvinnulifi samkvæmt jafnréttisskorkortinu? Til að svara pessum rannsóknarspurningum var safn mælikvarða dregið skipulega fram í formi jafnréttisskorkorts sem endurspeglar með tölulegum niðurstöðum stöðu kynjanna í íslensku atvinnulífi.

Eitt af fjölmörgum álitamálum við gerð skorkorts sem pessa er val á flokkum og mælikvörðum sem settir eru fram í skorkorti, en pað val tengist meðal annars afmörkun viðfangsefnisins. Með áđur birtu áhrifariti (Snjólfur Ólafsson o.fl., 2019) og síðan frumútgáfu af skorkorti (Pórunn Sigurðardóttir, 2018) var lagður grunnur að pessu vali. Pessi nálgun, að skilgreina áhrifarit og skorkort, er í eðli sínu ápekk pví sem skipulagsheildir gera pegar pær vinna stefnukort og skorkort í anda stefnumiðaðs árangursmats, t.d. fyrirtæki eða sveitarfélög (Khalid o.fl., 2019; Mendes o.fl., 2014; Ndevu og Muller, 2018; Wisniewski og Ólafsson, 2004). Með áhrifariti/stefnukorti eru sýnd meginatriði stefnu og örvar á milli atriðanna sýna áhrif eða orsakasamhengi (Kaplan og Norton, 2001a; Lawrie og Cobbold, 2004; Rigby, 2001, 2003). Með skorkorti eru teknar saman á einn stað, með lykilmælikvörðum, tölulegar upplýsingar sem sýna á skipulegan og markvissan hátt hvernig gengur að ná fram peirri stefnu sem kemur fram á áhrifaritinu. Pví nýtist slíkt safn vel til að lýsa stöðu kynjanna í íslensku atvinnulífi, en einnig mögulega til að draga upp framtíðarsýn og markmið um breytta stöðu (Syalom, 2015). Enda pó fjölmörg söfn talna og mælikvarða sem tengjast jafnrétti hafi verið sett fram, sjá töflu 9, pá eru pau mismunandi og ólík pví skorkorti sem sett er fram hér, með peirri undantekningu að í meistararitgerð Pórunnar Sigurðardóttur (2018) dregur hún fram frumútgáfu af pví jafnréttisskorkort sem sett er fram í pessari grein.

Jafnréttisskorkortið er safn 28 mælikvarða á stöðu kynjanna í atvinnulífinu og skiptist í fjóra flokka: Laun og atvinnupátttaka, Völd og áhrif, Náms- og starfsval og Fjölskylduábyrgð. Við val á mælikvörðum í fyrstu tveimur flokkunum var mest krefjandi að velja milli fjölmargra mælikvarða sem komu til greina og útfærslu sumra peirra. Tvö sjónarmið réðu miklu um valið, annars vegar að mælitækið gæfi miklar upplýsingar og hins vegar að forðast að einhverjir tveir mælikvarðar gæfu mjög svipaðar upplýsingar. Priðji flokkurinn er tvípættur, um kynjaskiptingu í æðstu störfum í fyrirtækjum og um kynjaskiptingu á Alpingi og í sveitarstjórnun. Hagstofan birtir miklar upplýsingar um kynjaskiptingu í fyrirtækjum og par fóst vinnan í að velja mælikvarða. Mest krefjandi var að velja mælikvarða í síðasta flokkinn, p.e. fjölskylduábyrgð. Ljóst er að ójöfn fjölskylduábyrgð hefur talsverð áhrif á ólíka stöðu kynjanna í atvinnulífinu, eins og áhrifaritið á mynd 1 dregur fram, en á sama tíma er erfitt að mæla hana og fá tölur sem veita gagnlegar upplýsingar. Niðurstaðan var að hafa fjóra mælikvarða í pessum flokki, par af tvo varðandi fæðingarorlof.

Áhrifaritið á mynd 1 er einn af útgangspunktunum við val á mælikvörðunum á jafnréttisskorkortinu á mynd 4. Eins og kemur fram í lok kafla 2 pá var ein af ályktunum rannsakenda eftir rýnifundina sú að líklega væri einna auðveldast að skilgreina og velja mælikvarða fyrir fjögur efnisatriði og eru pau auðkennd með sverari römmun. Skoðum pessi efnisatriði fyrst en tökum líka með atriðið „Minna kynjað námsval“ af pví að kynjaskipt námsval er nátengt kynjaskiptingu starfa.

"Minni launamunur" er mældur beint með mælikvörðum 1.1, 1.2, 1.3, 1.4 og 1.5. Mælikvarðar 1.6-1.8 snúast um pað að karlar vinna meira en konur, sem fræðimenn eru sammála um að sé ein af meginástæðunum fyrir óleiðréttum launamun kynjanna og er í takt við fyrri innlendar rannsóknir (Katrín Ólafsdóttir og Steinunn Rögnvaldsdóttir, 2015). „Minni kynjaskipting starfa“ er mælt með mælikvörðum 3.5 - 3.9 og „Minna kynjað námsval“ með mælikvörðum 3.1 - 3.4. „Jafnari hlutföll í framkvæmdastjórnum“ er mælt með 2.4 og 2.5. Mælikvarðar 2.1 - 2.3 eru um stjórnir fyrirtækja sem er nátengt pessu atriði, en petta er ekki sérstakt atriði á áhrifaritinu. ,JJafnari taka fæðingarorlofs“ er mælt beint með 
mælikvörðum 4.1 og 4.2. Peir mælikvarðar sem ekki hafa verið taldir upp eru $2.6-2.7$ og $4.3-4.4$, p.e. einungis 4 af 28 eru um atriði sem talið var að gæti verið erfitt að finna mælikvarða fyrir.

Áætla má að prjú atriði á áhrifaritinu: „Minni launamunur“, „Minni kynjaskipting starfa“ og „Jafnari hlutföll í framkvæmdastjórnum“ séu yfirmarkmið í stefnu um jafna stöðu kynjanna í íslensku atvinnulífi og á jafnréttisskorkortinu eru 12 mælikvarðar beint um pessi atriði. Aðrir mælikvarðar á jafnréttisskorkortinu eru einkum um atriði sem eru talin hafa mikil áhrif á pessi atriði og má par nefna lengri vinnutíma karla, námsval og fjölskylduábyrgð, eins og útskýrt er hér að framan. Mælikvarðar 2.6 og 2.7, um hlutföll kvenna á Alpingi og í sveitarstjórnun, gefa vísbendingu um nokkur atriði á áhrifaritinu og má sérstaklega nefna „Valdefling kvenna“ og „Fleiri fyrirmyndir karla og kvenna“. Mælikvarðar 4.3 og 4.4 snúast einkum um ,JJafnari fjölskylduábyrgð“ og pað gera að sjálfsögðu líka mælikvarðar 4.1 og 4.2, um töku fæðingarorlofs.

Sem svar við fyrri rannsóknarspurningunni er sett fram jafnréttisskorkort (mynd 4), sem gefur heildarmynd af stöðu kynjanna í íslensku atvinnulífi. Á myndum 5-11, eru sýndar tölur og próun fyrir mælikvarðana frá 1999-2018 í peim mæli sem mögulegt var. Á pennan hátt sýnir jafnréttisskorkortið bæði hver staða kynjanna er og hvernig hún hefur próast. Pegar pær upplýsingar eru skoðaðar er augljóst að talsvert vantar upp á að staða kynjanna í íslensku atvinnulífi sé jöfn. Sumir pættir hafa próast í átt að jöfnuði síðustu tvo áratugina en aðrir pættir hafa staðið í stað, eða að bil hefur minnkað lítillega.

Svarið við seinni rannsóknarspurningunni má lesa úr skorkortinu og er ljóst að samkvæmt fyrirliggjandi tölum er staða kvenna og karla ekki jöfn á íslenskum vinnumarkaði og hallar umtalsvert á konur. Hér fyrir neðan verða niðurstöðurnar ræddar út frá peim fjórum flokkum sem koma fram í skorkortinu: Laun og atvinnupátttaka, Völd og áhrif, Náms- og starfsval og Fjölskylduábyrgð.

\section{Laun og atvinnupátttaka}

Launamunur kynjanna hefur minnkað umtalsvert og má ætla að hann haldi áfram að minnka m.a. í tengslum við innleiðingu jafnlaunavottunar. Launamunur er pó mjög misjafn eftir hópum og fram kemur á mynd 5 að óleiðréttur launamunur er mun meiri en leiðréttur launamunur. Megin skýringin er sú að launaður vinnutími karla er lengri en kvenna. Pessar niðurstöður styðja innlendar rannsóknir sem sýna að karlar verja meiri tíma í launaðri vinnu á meðan konur verja meiri tíma í ólaunuðum heimilis- og umönnunarstörfum (Forsætisráðuneytið, 2020; Hagstofa Íslands o.fl., 2019; Katrín Ólafsdóttir og Steinunn Rögnvaldsdóttir, 2015; Kolbeinn Stefánsson, 2015; Póra Kristín Pórsdóttir og Kolbeinn Stefánsson, 2010). Einnig sýnir skorkortið að mun fleiri konur en karlar eru í hlutastarfi pó að hlutfallið hafi lækkað lítillega eða úr 80\% í 70\% á tímabilinu 2003-2018 (mynd 6).

\section{Völd og áhrif}

Hlutfall kvenna í stjórnum og sem framkvæmdastjórar hefur aukist stöðugt en hægt pegar horft er á öll fyrirtæki á tímabilinu 1999-2018 (mynd 7). Prátt fyrir að Ísland komi best út úr mælingum um jafna stöðu kynjanna í valdastöðum á Norðurlöndum (Gender Equality Barometer) fyrir árið 2019, standa konur höllum fæti pegar kemur að stjórnunarstöðum og formennsku í stjórnum stærri fyrirtækja (Júlíusdóttir o.fl., 2018; Lindahl, 2019; Unnur Dóra Einarsdóttir o.fl., 2017). Pegar litið er á áhrifastöður í fyrirtækjum sést að mesti kynjahallinn varðar framkvæmdastjóra fyrirtækja með fleiri en 50 starfsmenn og er ekki að merkja teljandi breytingu í takt við fjölgun kvenna í stjórnum slíkra fyrirtækja í kjölfar gildistöku kynjakvótalaganna 2010 (lög nr. 13/2010). Рað má pví ætla að næstu áratugina verði breytingar hægfara. Varðandi hlutfall kynjanna í sveitarstjórnum pá vantar ekki mikið upp á að jöfnuði sé náð, en samt er nokkuð í land og pó nokkrar sveiflur milli kosninga í hlutfalli kvenna á Alpingi. 
Náms- og starfsual

Sumar starfstéttir eru í dag hefðbundnar kvennastéttir og aðrar karlastéttir (Katrín Ólafsdóttir og Steinunn Rögnvaldsdóttir, 2015) og myndirnar sýna að nánast engin breyting hefur átt sér stað síðustu áratugi í peim starfstéttum sem mælikvarðar eru fyrir (mynd 10). Samkvæmt 18. grein laga (nr. 10/2008) varðandi réttindi og skyldur atvinnurekenda er lögð rík áhersla á að stuðla að pví að störf flokkist ekki í sérstök kvenna- og karlastörf. Ef vilji er til að minnka pennan mikla kynjamun pá er ein leið að leggja aukna áherslu á að námsval verði minna kynbundið og vinna að pví á margan hátt yfir langt tímabil. Áhrifarit Snjólfs Ólafssonar o.fl. (2019) og skorkortið í pessari rannsókn sýna fram á að ein af rótum vandans er kynbundið námsval og gefa myndirnar til kynna að lítil breyting hefur orðið par á (mynd 9). Færa má rök fyrir pví að nauðsynlegt sé að fara í einhvers konar pjóðarátak til að ná árangri á pví sviði. Öll skólastig skipta par máli: leikskólar, grunnskólar, framhaldsskólar og háskólar.

Fjölskylduábyrgð.

Karlar taka mun minni fjölskylduábyrgð en konur (sjá mynd 11), en ein af forsendum pess að jafna stöðu kynjanna í atvinnulífinu er að jafna fjölskylduábyrgð. Skipting ábyrgðar hefur jafnast hægt og bítandi frá 2005 til 2013, en samt er munurinn ennpá mjög mikill (mynd 11). Eins og fram hefur komið pá verja konur færri klukkustundum í launuð störf en karlar og ná par af leiðandi minni frama í fyrirtækjum en karlar (Forsætisráðuneytið, 2020; Hagstofa Íslands o.fl., 2019; Katrín Ólafsdóttir og Steinunn Rögnvaldsdóttir, 2015; Kolbeinn Stefánsson, 2015; Póra Kristín Pórsdóttir og Kolbeinn Stefánsson, 2010). Prátt fyrir aukna áherslu á jafnrétti kynjanna í íslensku atvinnulífi upplifa konur ennpá hindranir og ójöfn tækifæri á vinnumarkaði og er ein af ástæðum fyrir pví að konur verja meiri tíma í ólaunuðum heimilis- og umönnunarstörfum en karlar (Júlíusdóttir o.fl., 2018; Unnur Dóra Einarsdóttir o.fl., 2017). Pessar niðurstöður eru í takt við fyrri rannsóknir og sýna að prátt fyrir að réttur til fæðingarorlofs hafi verið jafnaður í lögum um fæðingar- og foreldraorlof sumarið 2000 (nr. 95/2000) nýta karlar síður fæðingarorlof en konur. Ætla má að pær breytingar sem urðu á fæðingarorlofskerfinu árið 2020 muni hafa merkjanleg áhrif, líkt og komu fram við breytingarnar árin 2000-2003, og verður fróðlegt að fylgjast með tölum á skorkortinu á næstu árum í ljósi pess, en reyndar mun áhrifanna ekki byrja að gæta fyrr en árið 2021.

Pessir fjórir flokkar sem koma fram í skorkortinu: Laun og atvinnupátttaka, Völd og áhrif, Náms- og starfsval og Fjölskylduábyrgð veita mikilvæga yfirsýn yfir núverandi stöðu kynjanna í íslensku atvinnulífi og varpa ljósi á mikilvæg atriði sem vert er að fylgja eftir. Рað er athyglisvert að prátt fyrir að nálægt tvöfalt fleiri konur en karlar hafi útskrifast með háskólagráđu frá aldamótum (Hagstofa Íslands, 2020), að atvinnupátttaka kvenna sé sú hæsta innan OECD (Hagstofa Íslands o.fl., 2019; OECD, 2019), að lög hafi verið sett um kynjakvóta í stjórnum fyrirtækja um að hvort kyn skyldi vera að lágmarki 40\% í fyrirtækjum með y fir 50 starfsmenn (lög um hlutafélög nr. 13/2010) pá virðist vera langt í land par til hlutfallið nái 50\% og par til að fullkomið jafnrétti náist á íslenskum vinnumarkaði.

Í pessari grein er í fyrsta sinn birt skorkort sem gefur heildarmynd af stöðu kynjanna í íslensku atvinnulífi, en frumútgáfa af slíku skorkorti var unnið í óbirtri meistararitgerð Pórunnar Sigurðardóttur (2018). Skorkort eru hugsuð sem verkfæri fyrir stjórnendur skipulagsheilda, t.d. fyrirtækja eða sveitarfélaga, til að greina hvaða aðgerða eða ákvarðana er pörf til að bæta árangur skipulagsheildarinnar (Khalid o.fl., 2019; Martin og Sauvageot, 2011; Mendes o.fl., 2014; Ndevu og Muller, 2018; Wisniewski og Ólafsson, 2004). Í pessu tilviki er skipulagsheildin Ísland, heil pjóð, og skorkortið er hugsað fyrir marga aðila, einkum fræðimenn, stjórnvöld og ýmis félagasamtök. Jafnréttisskorkortið er hægt að nota til að fylgjast með stöðunni og próun mála og leggja tölulegt mat á hvernig miðar. 
Jafnréttisskorkortið getur nýst við stefnumörkun í jafnréttismálum eða við einstaka ákvarðanir, m.a. auðveldað mat á mikilvægi einstakra pátta. Рað getur verið innlegg í vinnu við að velja aðgerðir eða skilgreina átaksverkefni sem eiga að stuðla að breytingum. Раð getur gagnast við að fylgjast með og meta próun mála, m.a. hvort árangur verði sýnilegur. Jafnréttisskorkortið getur jafnvel nýst einstökum stofnunum og fyrirtækjum sem vilja stuðla að auknu jafnrétti kynja í atvinnulífinu, m.a. með pví að skapa umræður innan peirra um aðgerðir sem að stjórnendur skipulagsheildanna geta gripið til eða stutt við.

Takmörkun rannsóknarinnar felst í pví að skorkort segja aldrei alla söguna pó svo að pau gefi gleggri mynd af stöðunni en til að mynda vísitölur eða söfn mælikvarða sem eru frekar almennir. Hafa parf í huga að flestar vísitölur fela í sér of mikla einföldun til að unnt sé að draga miklar ályktanir, t.d. gæti staða jafnréttis versnað mikið varðandi eitt atriði en batnað varðandi annað en vísitalan gefið sömu tölu. Pær veita einnig takmarkaðar upplýsingar um pað hvernig æskilegt er að vinna að úrbótum, til pess parf frekari sundurliðun á undirliggjandi páttum sem má gera með skorkorti. Jafnréttisskorkortið sem hér er kynnt hefur vissulega sína annmarka, sem og önnur sértæk skorkort. Til að mynda má nefna að oft eru ekki fyrirliggjandi gögn eða mælikvarðar fyrir pætti sem gæfu glögga mynd af tilteknum páttum, eins og t.d. fjölskylduábyrgð, sem hefur engu að síður umtalsverð áhrif á stöðuna sem ætlunin er að meta og/eða hafa áhrif á. Í slíkum tilvikum hjálpar að nýta mælikvarða sem gefa vísbendingar um stöðuna, frekar en að sleppa pví alfarið að taka umrædda pætti með í myndina. Pá getur purft að takmarka val á mælikvörðum við pá mælikvarða par sem hægt er að fá sambærilegar tölur fyrir á milli tímabila. Petta pýddi í raun að flestir mælikvarðar sem í greininni voru notaðir byggja á tölum sem Hagstofa Íslands birtir. Vissulega geta mælikvarðar aldrei sagt alla söguna en góðir mælikvarðar eru mjög mikilvægir ef vilji er til að vinna markvisst að pví að bæta tiltekið ástand.

Sem dæmi um mælikvarða sem æskilegt væri að hafa á jafnréttisskorkortinu en tókst ekki skilgreina og fá gögn um, var um hlut kvenna í fjölmiðlum. Félag kvenna í atvinnulífinu (FKA) hefur m.a. lagt áherslu á að auka sýnileika kvenna í atvinnulífinu og liður í pví er að konum fjölgi sem viðmælendum í fjölmiðlum (FKA, e.d.-b; FKA, e.d.-c). Í gegnum tíðina hafa fjölmargir tekið saman tölur varðandi pennan pátt en pað er ekki gert reglulega á sambærilegan hátt milli ára pannig að slíkur mælikvarða er ekki á jafnréttisskorkortinu. Alpjóðlega fjölmiðlavaktin (Global media monitoring project, GMMP) hefur verið framkvæmd á fimm ára fresti frá pví árið 1995 og hefur Ísland tekið fullan pátt frá árinu 2010. Framkvæmd fjölmiðlavaktarinnar er með peim hætti að fylgst er með kynjahlutföllum í öllum helstu fréttamiðlum (ljósvaka- og prentmiðlum) á einum tilteknum degi. Framkvæmdin og úrvinnslan er samræmd hjá öllum pátttökulöndunum (Valgerður Jóhannsdóttir og Porgerður Einarsdóttir, 2015). Par sem fjölmiðlavaktin tekur aðeins yfir einn dag á fimm ára fresti og tölurnar eru margar en hver um sig segir lítið og taka auk pess breytingum milli ára, pá var ákveðið að hafa ekki mælikvarða sem byggir á pessari könnun.

Skorkortið er liður í rannsóknarverkefni sem hófst á pví að setja fram áhrifarit fyrir stöðu kynjanna í íslensku atvinnulífi. Skorkortið getur nýst við áframhaldandi rannsóknir á viðfangsefninu, m.a. við að skilgreina/afmarka frekari rannsóknarverkefni eða sem útgangspunktur í rannsóknum. Sem dæmi má nefna rannsóknarverkefni sem snúa að kynbundnu náms- og starfsvali og hvort og pá hvernig hafa má áhrif á pá pætti, sé ætlunin að stuðla að auknu jafnrétti í atvinnulífinu. Einnig mætti skoða nánar áhrif fjölskylduábyrgðar á frama kvenna í atvinnulífinu. Pá mætti skoða betur kynjamun meðal framkvæmdastjóra í stórum fyrirtækjum, en verðugt verkefni væri að kortleggja með áhrifariti hvað gæti orðið til pess að veruleg breyting yrði par á. Pessu til viðbótar einskorðaðist rannsóknin við jafnrétti kvenna og karla en ekki annarra hópa. Pví væri hægt að próa, byggt á frekari rannsóknum og gagnaöflun, skorkort sem taka á málefnum annarra hópa í samfélaginu, t.d. fatlaðs fólks eða innflytjenda. 


\section{Heimildaskrá}

About the Agency (e.d.). Sótt 23. ágúst 2020 af https://www.wgea.gov.au/about-the-agency

Australia's gender equality scorecard (e.d.). Sótt 23. ágúst 2020 af https://www.wgea.gov.au/data/wgea-research/australias-gender-equality-scorecard

Ásta Dís Óladóttir, Gylfi Dalmann Aðalsteinsson og Póra H. Christiansen (2019). Er skortur á framboði eða er engin eftirspurn eftir konum í æðstu stjórnunarstöður? Stjórnmál E stjórnsýsla, 15(2), 205-228. doi:10.13177/ irpa.a.2019.15.2.4

CORE - Centre for Research on Gender Equality (2018). CORE Norwegian gender balance scorecard 2018. Institute for Social Research. Sótt af https://www.samfunnsforskning.no/core/bilder/core-topplederbarometer/core-topplederbarometer_pdf/core-norwegian-gender-balance-scorecard-2018.pdf

EIGE (2019). Gender equality index 2019: Work - life balance. Vilnius, Litháen: European Institute for Gender Equality. doi:10.2839/44985

Einarsdóttir, P. J. (2020). All that Glitters is Not Gold: Shrinking and Bending Gender Equality in Rankings and Nation Branding. NORA-Nordic Journal of Feminist and Gender Research, 1-13.

European Institute for Gender Equality (e.d.). Gender Equality Index. Sótt 3. mars 2020 af https://eige.europa. $\mathrm{eu} /$ gender-equality-index

Eurostat (e.d.). Long working hours in main job by sex, age, professional status and occupation [data]. Sótt 26. febrúar 2020 af https://appsso.eurostat.ec.europa.eu/nui/show.do?dataset=lfsa_qoe_3a2\&lang=en

Félag Sameinuðu pjóðanna á Íslandi (e.d.). Heimsmarkmiðin. Sótt 2. mars 2020 af http://www.un.is/heimsmarkmidin/

FKA (e.d.-a). Jafnvægisvog FKA - Mælaborð. Sótt 2. mars 2020 af https://www.fka.is/jafnvaegisvog-fka/maelabord/

FKA (e.d.-b). Fjölmiðlaverkefni FKA 2013-2017. Sótt 26. febrúar 2020 af https://www.fka.is/um/fjolmidlaverkefni-fka-2013-2017/

FKA (e.d.-c). FKA fjölmiðlapjálfun 2020 í húsakynnum RÚV Efstaleiti 1. (2020, 3. janúar). Sótt 26. febrúar 2020 af https://www.fka.is/um/frettir/fka-fjolmidlathjalfun-2020-i-husakynnum-ruv-efstaleiti-1

Forsætisráðuneytið (2019). Iceland's implementation of the 2030 agenda for sustainable development. Voluntary national review. Stjórnarrád Íslands.

Forsætisráðuneytið (2020). Jafnrétti 2020: Skýrsla forsætisráðherra um jafnréttismál 2018-2019. Lögð fram á jafnréttispingi 2020. Stjórnarráð Íslands og Jafnréttisráð.

Gná Guðjónsdóttir (2017). Samfélagsábyrð og sjálfbærni í ársskýrslum skipulagsheilda: Kerfisbundin leið til að ná fram markmiðum jafnréttislaga (óbirt meistararitgerð). Háskóli Íslands, Reykjavík. Sótt af http://hdl. handle.net/1946/28999

Guðrún Johnsen (2020). Náttúrulegt eðli eða uppeldi? Kynjamunur á áhættufælni. Vísbending, 38(5), 1-4.

Guide to reporting under the Workplace Gender Equality Act 2012 (e.d.). Sótt 23. ágúst 2020 af https://www. wgea.gov.au/guide-to-reporting

Hagstofa Íslands (2018). Hlutfall kvenna í stjórnum fyrirtæka stendur í stað milli ára. Sótt 7. mars 2020 af https://hagstofa.is/utgafur/frettasafn/fyrirtaeki/stjornir-og-framkvaemdastjorar-fyrirtaekja-2017/

Hagstofa Íslands (2020). Brautskráningar á háskólastigi og doktorsstigi eftir kyni [Talnaefni]. Sótt 7. mars 2020 af https://hagstofa.is/talnaefni/samfelag/menntun/haskolastig/

Hagstofa Íslands (e.d.-a). Óleiðréttur launamunur kynjanna 2008-2017 [Talnaefni]. Sótt 26. febrúar 2020 af http://px.hagstofa.is/pxis/pxweb/is/Samfelag/Samfelag_launogtekjur__1_laun__2_launamunurkynjanna/LAU02000.px/?rxid=28330685-33cf-47f3-9e28-5bceb8dd2795

Hagstofa Íslands (e.d.-b). Leiðréttur launamunur (OLS) 2000-2016 [Talnaefni]. Sótt 26. febrúar 2020 af http:// px.hagstofa.is/pxis/pxweb/is/Samfelag/Samfelag_launogtekjur__1_laun__2_launamunurkynjanna/ LAU02001.px/?rxid=28330685-33cf-47f3-9e28-5bceb8dd2795

Hagstofa Íslands (e.d.-c). Fjöldi og hlutfall starfandi fólks eftir árum 2003-2019 [Vinnumarkaðsrannsókn]. Sótt 26. febrúar 2020 af http://px.hagstofa.is/pxis/pxweb/is/Samfelag/Samfelag_vinnumarkadur_vinnumarkadsrannsokn_3_arstolur/VIN00931.px/?rxid=28330685-33cf-47f3-9e28-5bceb8dd2795

Hagstofa Íslands (e.d.-d). Meðalfjöldi unninna og venjulegra vinnustunda eftir árum 2003-2019 [Vinnumarkaðsrannsókn]. Sótt 26. febrúar 2020 af http://px.hagstofa.is/pxis/pxweb/is/Samfelag/Samfelag_vinnumarkadur_vinnumarkadsrannsokn_3_arstolur/VIN00941.px/?rxid=28330685-33cf-47f3-9e28-5bceb8dd2795

Hagstofa Íslands (e.d.-e). Framkvæmdastjórar og stjórnarmenn fyrirtækja eftir kyni og aldri 1999-2018 [Talnaefni]. Sótt 25. febrúar 2020 af http://px.hagstofa.is/pxis/pxweb/is/Atvinnuvegir/Atvinnuvegir_fyrirtaeki_ fjoldi_stjornir/FYR06101.px/?rxid=28330685-33cf-47f3-9e28-5bceb8dd2795

Hagstofa Íslands (e.d.-f). Kyn framkvæmdastjóra og stjórnarmanna eftir stærð fyrirtækja 1999-2018 [Talnaefni]. Sótt 25. febrúar 2020 af http://px.hagstofa.is/pxis/pxweb/is/Atvinnuvegir/Atvinnuvegir_fyrirtaeki_ fjoldi_stjornir/FYR06102.px/?rxid=28330685-33cf-47f3-9e28-5bceb8dd2795

Hagstofa Íslands (e.d.-g). Pingmenn kjörnir í alpingiskosningum eftir kyni og meðalaldri 1874-2017 [Talnaefni]. Sótt 26. febrúar 2020 af http://px.hagstofa.is/pxis/pxweb/is/Ibuar/Ibuar_kosningar_althingi_althkjornir/KOS02054.px/?rxid=28330685-33cf-47f3-9e28-5bceb8dd2795

Hagstofa Íslands (e.d.-h). Frambjóðendur og kjörnir fulltrúar í sveitarstjórnarkosningum 1950-2018 [Talnaefni]. 
Sótt 26. febrúar 2020 af http://px.hagstofa.is/pxis/pxweb/is/Ibuar/Ibuar_kosningar_yfirlit/KOS02008.px/ ?rxid=28330685-33cf-47f3-9e28-5bceb8dd2795

Hagstofa Íslands (e.d.-i). Brautskráningar úr starfsnámi á framhaldsskólastigi eftir námsbraut, prófgráđu og kyni 1995-2018 [Talnaefni]. Sótt 26. febrúar 2020 af http://px.hagstofa.is/pxis/pxweb/is/Samfelag/ Samfelag_skolamal__3_framhaldsskolastig__1_fsProf/SKO03206c.px/?rxid=28330685-33cf-47f3-9e285 bceb8dd2795

Hagstofa Íslands (e.d.-j). Brautskráningar á háskólastigi og doktorsstigi eftir almennu sviði, prófgráðu og kyni 1995-2018 [Talnaefni]. Sótt 26. febrúar 2020 af http://px.hagstofa.is/pxis/pxweb/is/Samfelag/Samfelag_ skolamal_4_haskolastig_1_hsProf/SKO04205.px/?rxid=28330685-33cf-47f3-9e28-5bceb8dd2795

Hagstofa Íslands (e.d.-k). Fjöldi starfandi eftir starfsstéttum, kyni og landssvæðum 1991-2019 [Vinnumarkaðsrannsókn]. Sótt 26. febrúar 2020 af http://px.hagstofa.is/pxis/pxweb/is/Samfelag/Samfelag_vinnumarkadur_vinnumarkadsrannsokn_3_arstolur/VIN01101.px/?rxid=28330685-33cf-47f3-9e28-5bceb8dd2795

Hagstofa Íslands (e.d.-1). Starfandi í aðalstarfi eftir atvinnugreinum (bálkar), kyni og búsetu 1991-2018 [Vinnumarkaðsrannsókn]. Sótt 26. febrúar 2020 af http://px.hagstofa.is/pxis/pxweb/is/Samfelag/Samfelag_vinnumarkadur_vinnumarkadsrannsokn_3_arstolur/VIN01105.px/?rxid=28330685-33cf-47f39e28-5bceb8dd2795

Hagstofa Íslands (e.d.-m). Meðaldagafjöldi foreldris í fæðingarorlofi eftir fæðingarári barns 2001-2017 [Talnaefni]. Sótt 27. febrúar 2020 af http://px.hagstofa.is/pxis/pxweb/is/Samfelag/Samfelag_born_6_felagsvernd/BOR06011.px/?rxid=28330685-33cf-47f3-9e28-5bceb8dd2795

Hagstofa Íslands, Jafnréttisstofa og forsætisráðuneytið (2019). Konur og karlar á Íslandi. Reykjavík: Hagstofa Íslands, Jafnréttisstofa og forsætisráðuneytið.

Hagtíðindi. (2018). Rannsókn á launamun kynjanna 2008-2016. Hagstofa Íslands.

Heimsmarkmiðin um sjálfbæra próun (e.d.). Sótt 2. mars 2020 af https://www.heimsmarkmidin.is/

ISSP (e.d.). ZA5900: International social survey programme: Family and changing gender roles. IV - ISSP 2012. Sótt 27. febrúar 2020 af https://dbk.gesis.org/dbksearch/sdesc2.asp?ll=10\&notabs=\&af=\&nf=\&search=\&search $2=\& \mathrm{db}=\mathrm{e} \& \mathrm{no}=5900$

Júlíusdóttir, Ó., Rafnsdóttir, G. L. og Einarsdóttir, P. (2018). Top Managers and the Gendered Interplay of Organizations and Family Life: The Case of Iceland. Gender in Management: An International Journal, 33(8), 602-622. doi:10.1108/gm-03-2017-0028

Jyrkinen, M. (2013). Women Managers, Careers and Gendered Ageism. Scandinavian Journal of Management, 30(2), 175-185. doi:10.1016/j.scaman.2013.07.002

Jyrkinen, M. og McKie, L. (2012). Gender, Age and Ageism: Experiences of Women Managers in Finland and Scotland. Work, Employment and Society, 26(1), 61-77. doi:10.1177/0950017011426313

Kaplan, R. S. og Norton, D. P. (1992, 1. janúar). The Balanced Scorecard-Measures that Drive Performance. Harvard Business Review, (January-February 1992).

Kaplan, R. S. og Norton, D. P. (1993). Putting the Balanced Scorecard to Work. Harvard Business Review, (September/October).

Kaplan, R. S. og Norton, D. P. (1996a). Linking the Balanced Scorecard to Strategy. California Management Review, 39(1). doi:10.2307/41165876

Kaplan, R. S. og Norton, D. P. (1996b). The Balanced Scorecard: Translating Strategy into Action. Harvard Business Press.

Kaplan, R. S. og Norton, D. P. (2001a). Transforming the Balanced Scorecard from Performance Measurement to Strategic Management: Part I. Accounting Horizons, 15(1), 87-104. doi:10.2308/acch.2001.15.1.87

Kaplan, R. S. og Norton, D. P. (2001b). The Strategy-Focused Organization: How Balanced Scorecard Companies Thrive in the New Business Environment. Boston, Massachusetts: Harvard Business Press.

Katrín Ólafsdóttir og Steinunn Rögnvaldsdóttir (2015). Staða kvenna og karla á íslenskum vinnumarkaði. Staðreyndir og staða pekkingar. Reykjavík: Velferðarráðuneytið.

Khalid, S., Beattie, C., Sands, J. og Hampson, V. (2019). Incorporating the Environmental Dimension into the Balanced Scorecard: A Case Study in Health Care. Meditari Accountancy Research, 27(4), 652-674. doi:10.1108/MEDAR-06-2018-0360

Kolbeinn Stefánsson (2015). Viðauki 1: Verkaskipting, vinna og heimili. Í Staða kvenna og karla á íslenskum vinnumarkaði: Staðreyndir og staða pekkingar. Reykjavík: Velferðarráðuneytið.

Kristín Guðmundsdóttir og Eðvald Möller (2012). Viðskiptagreind. Í Ingjaldur Hannibalsson (ritstjóri), Rannsóknir í félagsvísindum XIII. Erindi flutt á ráđstefnu í október 2012. Félagsvísindastofnun Háskóla Îslands.

Lanninger, A. W. og Sundström, M. (2014). Part-Time Work in the Nordic Region: Part-Time Work, Gender and Economic Distribution in the Nordic Countries. Denmark: Norden. doi:10.6027/TN2014-503

Launamunur kynjanna (e.d.). Sótt 26. febrúar 2020 af http://www.vr.is

Lawrie, G. og Cobbold, I. (2004). Third-Generation Balanced Scorecard: Evolution of an Effective Strategic Control Tool. International Journal of Productivity and Performance Management, 53(7), 611-623. doi:10.1108/17410400410561231

Lindahl, B. (2019, 6. mars). Nordic Power Positions: A Modest Increase in Gender Equality. Nordic Labour Journal. Sótt af http://www.nordiclabourjournal.org/i-fokus/in-focus-2019/gender-equality-barometre-2019/ article.2019-03-04.2406255703 
Lög um 40 stunda vinnuviku nr. 88/1971.

Lög um breytingu á lögum um hlutafélög og lögum um einkahlutafélög nr. 13/2010.

Lög um einkahlutafélög nr. 138/1994.

Lög um félagslega aðstoð nr. 99/2007.

Lög um fæðingar- og foreldraorlof nr. 95/2000.

Lög um hlutafélög nr. 2/1995.

Lög um jafna meðferð á vinnumarkaði nr. 86/2018.

Lög um jafna stöðu og jafnan rétt kvenna og karla nr. 10/2008.

Mack, P. (2014). Big Data, Data Mining, and Predictive Analytics and High Performance Computing. Í J. Lawrence (ritstjóri), Renewable energy integration: Practical management of variability, uncertainty, and flexibility in power grids (1. útg.). Cambridge: Academic Press.

Martin, M. og Sauvageot, C. (2011). Constructing an Indicator System or Scorecard for Higher Education. A Practical Guide. Paris, France: International Institute for Educational Planning. Sótt af http://uis.unesco. org/sites/default/files/documents/constructing-an-indicator-system-or-scorecard-for-higher-education-apractical-guide-2011-en.pdf

Melchert, F., Winter, R. og Klesse, M. (2004). Aligning Process Automation and Business Intelligence to Support Corporate Performance Management. Í 507. Flutt á Tenth Americas Conference on Information Systems, New York, NY.

Mendes, P., Nunes, L. M. og Teixeira, M. R. (2014). Quantitative Performance Targets by using Balanced Scorecard System: Application to Waste Management and Public Administration. Waste Management \& Research, 32(9), 927-936. doi:10.1177/0734242X14540977

Ndevu, Z. J. og Muller, K. (2018). Operationalising Performance Management in Local Government: The Use of the Balanced Scorecard. SA Journal of Human Resource Management, 16(0), 11. doi:10.4102/sajhrm. v16i0.977

Oaxaca, R. (1973). Male-Female Wage Differentials in Urban Labor Markets. International Economic Review, 14(3), 693-709. doi:10.2307/2525981

OECD (2019). Employment rate [data]. doi:10.1787/1de68a9b_en (Sótt 7. mars 2020)

OSAGI og OFPW (2010). Gender Balance Strategy for the United Nations Secretariat: A Strategic Action Plan. Sótt af https://www.un.org/womenwatch/osagi/ianwge/NEW\%20Gender\%20Balance\%20Strategy_ march\%202010_Anex\%206.pdf

Radl, J. (2012). Too Old to Work, or Too Young to Retire? The Pervasiveness of Age Norms in Western Europe. Work, Employment and Society, 26(5), 755-771. doi:10.1177/0950017012451644

Reglugerð um sveinspróf nr. 698/2009.

Rigby, D. (2001). Management Tools and Techniques: A Survey. California Management Review, 43(2), 139_ 160. doi:10.2307/41166079

Rigby, D. (2003). Management Tools Survey 2003: Usage Up as Companies Strive to Make Headway in Tough Times. Strategy \& Leadership, 31(5), 4-11. doi:10.1108/10878570310492005

Shamsuzzoha, A., Hao, Y., Helo, P. T. og Khadem, M. K. (2014). Dashboard User Interface for Measuring Performance Metrics: Concept from Virtual Factory Approach. Flutt á The 2014 International Conference on Industrial Engineering and Operations Management, Bali, Indonesia. Sótt af http://www.iieom.org/ ieom2014/pdfs/34.pdf

Sigurður Snævarr (2015). Launamunur karla og kvenna. Velferðarráðuneytið.

Snjólfur Ólafsson (2005). Stefnumiðað árangursmat sem liður í að framkvæma stefnu. Tímarit um viðskipti og efnahagsmál, 3(1), 47-72. doi:10.24122/tve.a.2005.3.1.3

Snjólfur Ólafsson, Erla S. Kristjánsdóttir, Lára Jóhannsdóttir og Póra H. Christiansen (2019). Pættir sem hafa áhrif á stöðu kynjanna í íslensku atvinnulífi: Heildarmynd sýnd með áhrifariti. Tímarit um viðskipti og efnahagsmál, 16(1), 71-88. doi:10.24122/tve.a.2019.16.1.5

Stjórnarráð Íslands (e.d.-a). Tölfræði heimsmarkmiðanna. Sótt 2. mars 2020 af https://www.stjornarradid.is/ verkefni/utanrikismal/throunarsamvinna/heimsmarkmidin/tolfraedi-heimsmarkmidanna/

Stjórnarráð Íslands (e.d.-b). Heimsmarkmiðin. Mælikvarðar fyrir markmið 5. Sótt 2. mars 2020 af https:// www.stjornarradid.is/verkefni/utanrikismal/throunarsamvinna/heimsmarkmidin/tolfraedi-heimsmarkmidanna/maelikvardar-5/

Syalom (2015). Design of a Balanced scorecard on nonprofit organizations (Study on Yayasan Pembinaan dan Kesembuhan Batin Malang ). Journal of Business and Management, 17(12), 7-14. doi:10.9790/487X-171220714

Tryggingastofnun (e.d.). Lífeyrispegar, greiðslur lífeyristrygginga, félagslegrar aðstoðar og greiðslur til foreldra eftir kyni [Tafla 1.3 og 1.4]. Sótt 27. febrúar 2020 af https://qlik.capacent.is/extensions/TRS03/TRS03. html

United Nations Development Programme (2020). Human development perspectives: Tackling social norms - a game changer for gender inequalities. New York, NY: UNDP.

Unnur Dóra Einarsdóttir, Erla S. Kristjánsdóttir og Póra H. Christiansen (2017). ...hvað segið pið strákar? Upplifun kvenmillistjórnenda af stöðu sinni, möguleikum og hindrunum í starfi. Tímarit um viðskipti og efnahagsmál, 14(1), 1-24. doi:10.24122/tve.a.2017.14.1.1

Valgerður Jóhannsdóttir og Porgerður Einarsdóttir (2015). Gender Bias in the Media: The Case of Iceland. 
Stjórnmál og stjórnsýsla, 11(2), 207-230. doi:10.13177/irpa.a.2015.11.2.5

Velferðarráðuneytið (2018). Skýrsla félags- og jafnréttismálaráðherra um stöðu og próun jafnréttismála 20152017. Reykjavík: Velferðarráðuneytið.

WGEA Data (e.d.). Sótt 23. ágúst 2020 af https://www.wgea.gov.au/data

Wijk, S. F. (2007). The Gender Balanced Scorecard. A Management Tool to Achieve Gender Mainstreaming in Organisational Culture. Zeitschrift für Personalforschung / German Journal of Research in Human Resource Management, 21(4), 486-489. doi:10.1177/239700220702100443

Wisniewski, M. og Ólafsson, S. (2004). Developing Balanced Scorecards in Local Authorities: A Comparison of Experience. International Journal of Productivity and Performance Management, 53(7), 602-610. doi:10.1108/17410400410561222

World Economic Forum (2020). Global Gender Gap Report 2020. Geneva, Switzerland: World Economic Forum.

Workplace Gender Equality Act (2012) [Act No. 91 of 1986 as amended].

Workplace Gender Equality Agency (2019). Australia's Gender Equality Scorecard. Key Findings from the Workplace Gender Equality Agency's 2018-19 Reporting Data. Sydney: Workplace Gender Equality Agency. Sótt af https://www.wgea.gov.au/sites/default/files/documents/2018-19-Gender-Equality-Scorecard.pdf

Porgerður Einarsdóttir og Kristjana Stella Blöndal (2004). Kynbundinn launamunur: umræðan um skýrðan og óútskýrðan launamun kynja í gagnrýnu ljósi. Í Irma Erlingsdóttir (ritstjóri), Fléttur II. Kynjafræði - kortlagningar (bls. 247-271). Reykjavík: Rannsóknastofa í kvenna- og kynjafræðum við Háskóla Íslands.

Póra Kristín Pórsdóttir og Kolbeinn Stefánsson (2010). Verkaskipting kynjanna fyrir og eftir bankahrun. Fréttabréf Pjóðmálastofnunar Háskóla Íslands. Reykjavík.

Pórunn Sigurðardóttir (2018). Ísland best í heimi? Safn mælikvarða sem sýna stöðu kynjanna í íslensku atvinnulífi (óbirt meistararitgerð). Háskóli Íslands, Reykjavík. Sótt af http://hdl.handle.net/1946/29337 
